\title{
An estimate of the terrestrial carbon budget of Russia using inventory-based, eddy covariance and inversion methods
}

\author{
A. J. Dolman ${ }^{1}$, A. Shvidenko ${ }^{2}$, D. Schepaschenko ${ }^{2}$, P. Ciais ${ }^{3}$, N. Tchebakova ${ }^{4}$, T. Chen ${ }^{1}$, M. K. van der Molen ${ }^{1,5}$, \\ L. Belelli Marchesini ${ }^{1}$, T. C. Maximov ${ }^{6}$, S. Maksyutov ${ }^{7}$, and E.-D. Schulze ${ }^{8}$ \\ ${ }^{1}$ Department of Earth Sciences, Vrije Universiteit Amsterdam, Boelelaan 1085, 1081 HV, Amsterdam, The Netherlands \\ ${ }^{2}$ International Institute for Applied Systems Analysis (IIASA), Schlossplatz 1, 2361 Laxenburg, Austria \\ ${ }^{3}$ IPSL - LSCE, CEA CNRS UVSQ, Centre d'Etudes Orme des Merisiers, 91191 Gif sur Yvette, France \\ ${ }^{4}$ V. N. Sukachev Institute of Forest of SB RAS 660036, Krasnoyarsk, Russia, Akademgorodok, SIF SB RAS and Siberian \\ Federal University, Krasnoyarsk, Russia \\ ${ }^{5}$ Wageningen University, Department of Meteorology and Air Quality, Wageningen, The Netherlands \\ ${ }^{6}$ Institute for Biological Problems of Cryolithozone Siberian Branch of RAS, 677980, 41, Lenina avenue, Yakutsk, Russia \\ ${ }^{7}$ Center for Global Environmental Research, National Institute for Environmental Studies Onogawa 16-2, Tsukuba, Ibaraki \\ 305-8506, Japan \\ ${ }^{8}$ Max Planck Institute for Biogeochemistry, Jena, Germany
}

Correspondence to: A. J. Dolman (han.dolman@vu.nl)

Received: 9 March 2012 - Published in Biogeosciences Discuss.: 6 June 2012

Revised: 31 October 2012 - Accepted: 27 November 2012 - Published: 20 December 2012

\begin{abstract}
We determine the net land to atmosphere flux of carbon in Russia, including Ukraine, Belarus and Kazakhstan, using inventory-based, eddy covariance, and inversion methods. Our high boundary estimate is $-342{\mathrm{Tg} \mathrm{C} \mathrm{yr}^{-1}}^{-1}$ from the eddy covariance method, and this is close to the upper bounds of the inventory-based Land Ecosystem Assessment and inverse models estimates. A lower

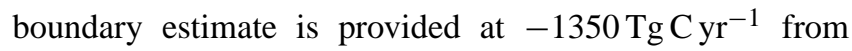
the inversion models. The average of the three methods is

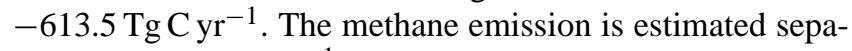

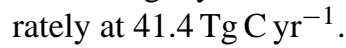

These three methods agree well within their respective error bounds. There is thus good consistency between bottomup and top-down methods. The forests of Russia primarily cause the net atmosphere to land flux $\left(-692 \mathrm{Tg} \mathrm{C} \mathrm{yr}^{-1}\right.$ from the LEA. It remains however remarkable that the three methods provide such close estimates $(-615,-662$,

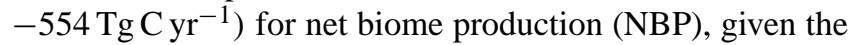
inherent uncertainties in all of the approaches. The lack of recent forest inventories, the few eddy covariance sites and associated uncertainty with upscaling and undersampling of concentrations for the inversions are among the prime causes of the uncertainty. The dynamic global vegetation models
\end{abstract}

(DGVMs) suggest a much lower uptake at $-91 \mathrm{Tg} \mathrm{C} \mathrm{yr}^{-1}$, and we argue that this is caused by a high estimate of heterotrophic respiration compared to other methods.

\section{Introduction}

The carbon balance of Russia plays an important role in the global carbon cycle, primarily due to its large areas of forest and peat- and wetlands and its enormous soil carbon reservoirs. Tundra and wetland make up about $25 \%$ of the total area; $49 \%$ of Russia is forested while agriculture and grassland make up the remaining $26 \%$ (Fig. 1).

Because only a small area of Russia exists south of $50^{\circ} \mathrm{N}$ and more than half of the country lies north of $60^{\circ} \mathrm{N}$, large regions of Russia experience six months of snow cover and soils that are permanently frozen. For instance, the Lena basin is almost covered completely by permafrost, at places up to several hundred meters depth. In these areas, over thousands of years, large stores of carbon in lake sediments and in wetland, forest and tundra soils were created. This could happen because the low temperatures at northern latitudes inhibit microbial decomposition, while carbon input through 
photosynthesis could remain at high levels during the boreal spring and summers. Consequently, there are now large stores of carbon (C) in northern high latitude regions, particularly in permafrost regions (International Arctic Science Committee, 2010).

IASC (2010), McGuire et al. (2009) and Tarnocai et al. (2009) in, what are probably the most up to date and comprehensive reviews of the Arctic carbon balance, estimate soil carbon storage of northern high latitude terrestrial ecosystems to be between 1400 and $1850 \mathrm{Pg}$ in the upper three meters of soil. The precise magnitude and spatial variability remain largely unknown. Schepaschenko et al. $(2011 b, 2012 b)$ estimated the stock of organic carbon in the Russian Federation (RF) at $323 \mathrm{Pg}$ in the first $1 \mathrm{~m}$ of the soil, including $16 \mathrm{Pg} \mathrm{C}$ in the on-ground organic layer. Zimov et al. (2006) argue that there exists approximately $400 \mathrm{Pg}$ of carbon in currently frozen soils that was accumulated in nonglaciated regions during the Pleistocene, in what was then steppe-tundra vegetation. These carbon-rich loess soils are called Yedoma sediments. Another $250 \mathrm{Pg} \mathrm{C}$ may be stored in deep alluvial sediments below $3 \mathrm{~m}$ in river deltas of the seven major Arctic rivers (Schuur et al., 2008), with half of this alluvial carbon being in the Lena delta (Tarnocai et al., 2009).

Not only soil carbon stocks make the boreal zone of Russia an important player in the global carbon balance. NOAA-AVHRR NDVI (normalized difference vegetation index) trend studies have indicated greening trends in the area (Myneni et al., 1997; Zhou et al., 2001). Increasing temperature and the lengthening of the growing season (Serreze et al., 2000; Chapin et al., 2005) would cause enhanced biospheric activity (Lucht et al., 2002; Beer et al., 2006; Chen et al., 2006). A recent study of NOAA-AVHRR NDVI trends indicates a decrease in photosynthetic activity (browning) during 1997-2006, following the greening signal observed during 1982-1997 (Piao et al., 2011 and Serreze and Barry, 2011). Piao et al. (2008) and Parmentier et al. (2011) indicate that at the end of the growing season enhanced respiration may reduce the gains in uptake from the spring. Atmospheric inverse models (Bousquet et al., 1999; Gurney et al., 2002; Rödenbeck et al., 2003) and forest inventory studies (Nilsson et al., 2000; Shvidenko and Nilsson, 2003) confirm that there is a carbon dioxide sink in the RF, but the precise magnitude of the sink is still a matter of considerable debate. More recently, Quegan et al. (2011) presented a multiple constrained analysis of the carbon budget of a large region ( $300 \mathrm{Mha})$ in Central Siberia using forest inventory, remotely sensed data and modeling. They concluded that, in particular, heterotrophic respiration and disturbance were not well represented in the dynamic global vegetation models (DGVMs) used. Ciais et al. (2010), in an analysis of the Northern Hemispheric $\mathrm{C}$ budget, suggest the existence of a net biosphere to land flux of $\mathrm{CO}_{2}$ of the order of -0.6 to $-1 \mathrm{Pg} \mathrm{C} \mathrm{yr}^{-1}$ for Russia during the period 2000-2004. They also found consistency between the bottom-up and top-down estimates, within the reported uncertainties of each approach.

Since the early 1990s, Russia has seen some important political developments that bear on the carbon cycle dynamics at continental scale. After the collapse of the Soviet collective farming system, a significant decrease in area of agricultural lands in the Russian Federation occurred. According to the official Russian statistics (Kurganova et al., 2010a), 43 Mha of agricultural lands (including 30.2 Mha of arable) were abandoned after 1990, and the ratio between croplands and grasslands was significantly changed. Another estimate for 2009 accounted for 30 Mha of arable lands which have not been converted to forest (Shvidenko et al., 2010a). This was by far the largest land use change (LUC) of the 20th century in the Northern Hemisphere (Lyuri et al., 2010), of which the implications for shifts in $\mathrm{C}$ budgets and pools of the territory of the Russian Federation still need to be confirmed. Current estimates of $\mathrm{C}$ accumulation in grassland soils after abandonment are uncertain, with estimates of the biosphere to atmosphere flux from $-8 \mathrm{Tg} \mathrm{C} \mathrm{yr}^{-1}$ (Vuichard, et al., 2008) to $-45 \mathrm{Tg} \mathrm{C} \mathrm{yr}^{-1}$ (Kurganova et al., 2010a,b), mostly in European Russia. In Kazakhstan, where cropland area decreased by $40 \%$ between 1990 and 1996 due to abandonment, a $\mathrm{C}$ sink could exist as well but has not been estimated.

We provide here an integrated analysis of the full terrestrial carbon budget of Russia based on four different methods (e.g. Schulze et al., 2009). The analysis includes all terrestrial and inner aquatic ecosystems (lakes, rivers and other water reservoirs). It should ideally also include fluxes of all important carbon contained in gases (carbon dioxide, $\mathrm{CO}_{2}$; carbon monoxide, $\mathrm{CO}$; methane, $\mathrm{CH}_{4}$; and non-methane hydrocarbons, NMHC), particles and aerosols to the atmosphere, hydrosphere and lithosphere in a spatially and temporally explicit way. While we currently cannot achieve this complete picture, we do present an estimate of the $\mathrm{CH}_{4}$ balance that is of critical importance in establishing the vulnerability of the permafrost system to climate change. To be useful in guiding both policy implications and further research, we also assess the uncertainties involved (Shvidenko et al., 2010b).

We use a comprehensive landscape-based inventory method (LEA), developed at IIASA (Shvidenko et al., 2010a; Schepaschenko et al., 2011a), to make estimates of C stocks and fluxes. Further observational constraints come in the form of eddy covariance data from a network of ecological observatories (M. J. van der Molen, personal communication, 2012) and an analysis of inverse model estimates that provide a top-down constraint on the budgets. Bottom-up Dynamic Vegetation Models (DGVMs) are used to provide insight into the mean and interannual variability in fluxes. 


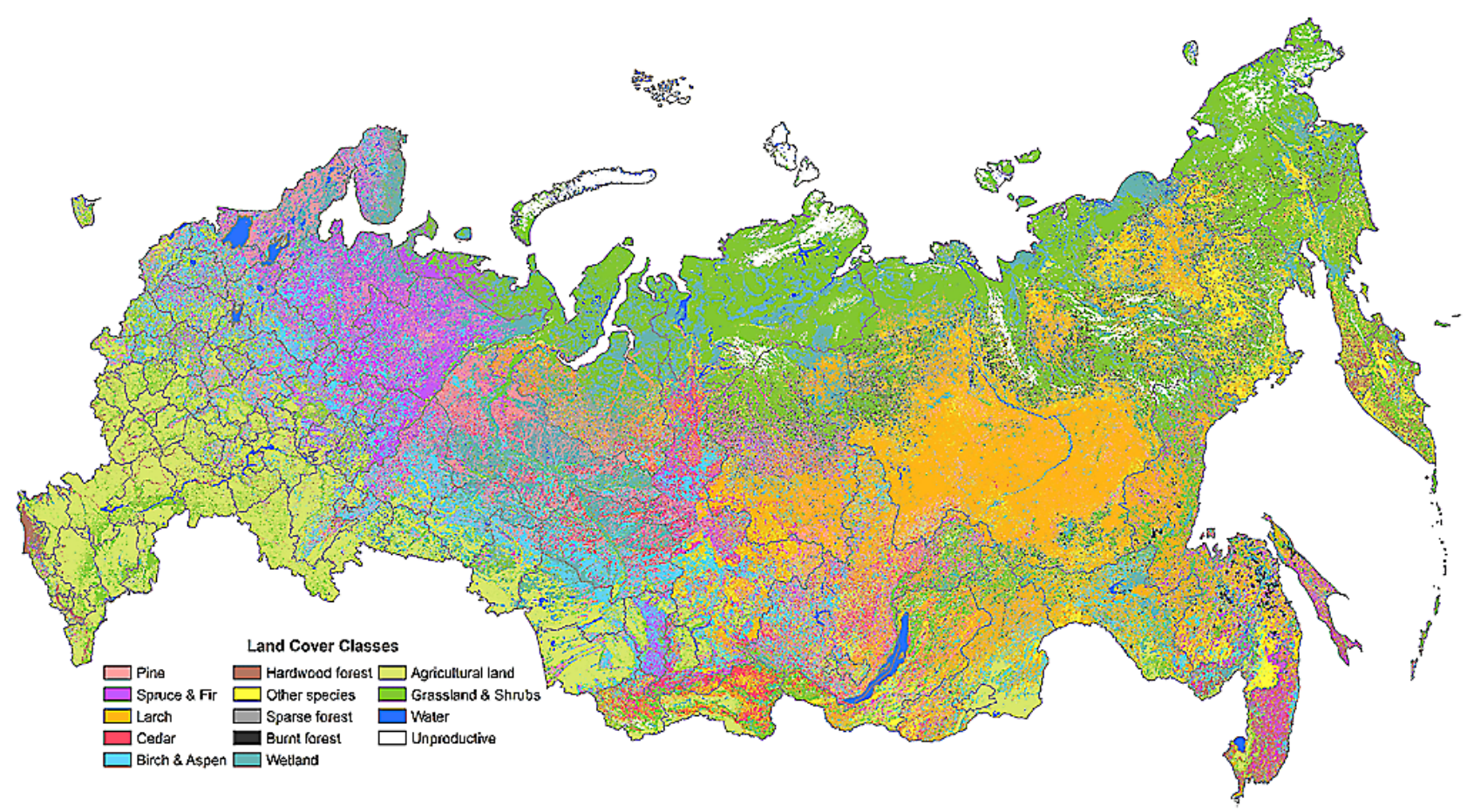

Fig. 1. Vegetation (land cover) classification in Russia specifically made for estimating greenhouse gas fluxes and stocks (from Schepaschenko et al., 2011a).

\section{Methodology and data sources}

\subsection{Land Ecosystem Assessment (LEA)}

Within the LEA, the accounting schemes for carbon budgets are a combination of flux-based and pool-based approaches. The fluxes of net biome production (NBP), net ecosystem production (NEP) and net primary production (NPP) are calculated together with autotrophic and heterotrophic soil respiration and the flux due to the decomposition of dead wood. The lateral outflow of carbon consists of the flux to the lithosphere (weathering) and the flux to the hydrosphere in dissolved and particulate (in)organic carbon through rivers. A separate calculation concerns the fluxes caused by natural and human-induced disturbances, net flux due to trade and the consumption of plant products. The precise combination of fluxes used depends on the precise selection of final domain boundaries (see below). In the pool-based approach the fluxes are calculated from the time difference in stocks. Poor knowledge of, for instance, carbon pools in soils poses severe restrictions on the use of the pool-based method, but for some applications like forest biomass estimated from forest inventories, it provides useful results (Pan et al., 2011).

The empirical basis for the LEA is the Integrated Land Information System (ILIS) for Russia developed by IIASA. The ILIS includes a Hybrid Land Cover (HLC, Fig. 1) and several attributive datasets of available measurements. The HLC for the Russian territory was developed based on the integration and harmonization of multi-sensor remote sensing products (GLC-2000, MODIS VCF, AVHRR, LANDSAT TM, ENVISAT ASAR, others) and available in-situ data (e.g. State Land Account, State Forest Account, data on natural and human-induced disturbances). The downscaling and parametrization of the HLC is performed for each $1 \mathrm{~km}$ pixel using a special optimization algorithm. Details of the approach are described in (Schepaschenko et al., 2011a). Arguably, this product is one of the most accurate descriptions and classifications of terrestrial ecosystems of Russia.

Major components of the LEA were defined by sets of different empirical models applied by land classes and bioclimatic zones. Net primary production (NPP) was assessed based on several in-situ measurements (beside those of forests). Forest NPP was estimated by an original, arguably unbiased approach (Shvidenko et al., 2007). These estimates of NPP do not allow separate estimates of $\mathrm{CO}_{2}$ fertilization and nitrogen deposition effects. Heterotrophic soil respiration $\left(\mathrm{H}_{\mathrm{SR}}\right)$ was assessed through a special accounting system by identifying type of soil, vegetation class and bioclimatic zone, with corrections applied for climatic characteristics of individual growth seasons.

About half of the Russian forests have been inventoried more than $25 \mathrm{yr}$ ago (Solontsov, 2010). Thus, data of forest inventories should be treated with considerable caution as their validity depends on the reliability of updating the obsolete forest inventory data. Very few studies have access to the relevant combination of remote sensing, ground 
measurements and empirical models to be able to update reported forest inventory data. (Pan et al. 2011). Two periods were included in the Pan et al. (2011) analysis: 1990-1999 and 2000-2007. In order to estimate dynamics of soil and dead wood carbon, data of detailed snapshot inventories from 2007 have been used. The carbon dynamics for the above periods were estimated from empirical models of input for organic matter into soil and impacts of disturbances on carbon pools. The analysis was performed separately for European and Asian Russia.

The fluxes due to disturbances were defined as the product of the disturbed area and amount of transformed carbon, the calculation schemes accounted for the specifics of each individual type of disturbance (e.g. a modified approach of Seiler and Crutzen (1980) was used in LEA for wild fires). The consumption of plant products (agriculture, forest) was calculated based on official statistical data including imports and exports.

Agricultural land includes currently cultivated and abandoned arable land (that has not been transferred into forest), fallows, cultivated pastures and hayfields. The carbon balance of agricultural land was estimated by accounting all the relevant fluxes of carbon. Thus, it includes on the carbon gain side net primary production, the effects of the application of fertilizers and liming. Carbon losses include soil respiration, disturbances if relevant (i.e. fire), the lateral flux and consumption. The initial data used comes from Federal State Statistics Service reports (FSSS, 2009) by administrative units ( 81 in total). The following indicators were used: land structure (crops, hayfield, pasture, fallow), seeded area by crop type (grains, industrial crops, vegetables, feed crops), harvest by crop, and fertilization (Schepaschenko et al., 2012a).

Empirical equations (Rodin and Krylatov, 1998) were used to assess live biomass fraction and NPP based on the harvest. Crop residuals were estimated as the difference between net primary production and harvest (based on climatic indicators, soil and land use types). Crop residuals were accounted for as an input of organic matter to the soil carbon pool.

Error calculation of the different components was achieved by running a Monte Carlo analysis as described in Shvidenko et al. (2010b).

\subsection{Eddy covariance estimates}

Data were used from 14 sites representing the main ecosystem types in Siberia and European Russia, as listed in Supplement Table S1. From west to east they are an oligotrophic bog, a wet and a dry spruce forest near Tver in the territory of the Central Forest Biosphere State Reserve, $350 \mathrm{~km}$ west of Moscow in European Russia; a natural grassland-steppe near Hakasia in southern Central Siberia (HAK1), a regenerating grassland on agricultural fields abandoned in 1999 (HAK2) and one on fields abandoned in 1994 (HAK3); a bog, a pine forest, a mixed forest and a Siberian fir forest near Zotino in Central Siberia; a larch and a pine forest near Yakutsk in Eastern Siberia; a typical tundra site near Chokurdakh in Northeastern Siberia; and a tussock sedge tundra site on a floodplain near the latitudinal tree line near Cherskii in the far northeast of Siberia. Thus, the major ecosystem types taiga, tundra, steppe and taiga-bog mosaic are represented.

Half-hourly net ecosystem exchange (NEE) fluxes were first integrated into daily NEE totals. Half-hourly data was treated for nighttime corrections and gap-filled according to standard procedures (Reichstein et al., 2005; Papale et al., 2006). Daily totals were accepted only when more than $80 \%$ of the hourly values of a day were present, otherwise they were gap filled. For each site, the daily NEE data were grouped into 61 blocks of 6 days and averaged over all available years. This results in average annual cycles of NEE for all sites, except for Cherskii and Hakasia HAK1, which each required one unfilled block to be filled by linear interpolation. Considering the rather smooth course of NEE, this does probably not introduce a large error. As a first estimate, we assume that unobserved wintertime NEE fluxes are zero. This may be an assumption that causes an overestimation of the uptake. For instance, the spruce forest in Federovskaya shows an estimated loss during winter of around $100 \mathrm{~g} \mathrm{C} \mathrm{m}^{-2}$ (Wang et al., 2010), however for forest and tundra experiencing stronger winters, this would be less. In the absence of measurements under those conditions, we cannot reliably estimate this quantity further. The annual net ecosystem productivity (NEP) results from integrating the annual course of NEE.

\subsection{Inverse model estimates}

We use the results of 12 inverse models, projected on the RECCAP Russia mask. The data are available mostly from 1990-2008. Table 2 gives a listing of the inversion schemes used (see also R. Gurney, personal communication, 2012 for further detail). Inversions provide estimates of net atmosphere to land $\mathrm{CO}_{2}$ fluxes, assuming known fossil fuel $\mathrm{CO}_{2}$ emissions. The land-atmosphere residual $\mathrm{CO}_{2}$ flux is calculated by removing these fossil fuel $\mathrm{CO}_{2}$ emissions from the net flux.

\subsection{DGVMs}

We use the results of 8 DGVMs (Sitch et al., 2008) whose data was collected for the purpose of the TRENDY intercomparison (http://dgvm.ceh.ac.uk) and made available to the RECCAP (Regional Carbon Cycle Assessment and Processes) (Canadell et al., 2011) participants. The models are run with a merged CRU-NCEP forcing dataset over 19012009 (http://dods.extra.cea.fr/data/p529viov/) and provide at their grid resolution, typically 1 degree, estimates of GPP, NPP, NEP and/or NBP. Respiration can also be obtained from these data. The models used are CLM4, ORCHIDEE, HYLAND, LPJGuess, LPJ, OCN, SDGVM, and TRIFFID (http: 
//www-lscedods.cea.fr/invsat/RECCAP/). In the simulations an actual, non-dynamic land cover was used. The models are run to equilibrium with a $286 \mathrm{ppm} \mathrm{CO}_{2}$ concentration driven by 1901-1920 climatology. From there a changing climate and $\mathrm{CO}_{2}$ are prescribed and the runs are executed from 19012009. The data for the geographical area of Russia are obtained using the RECCAP mask. We included Kazakhstan, Ukraine and Belarus in our current estimates.

In addition to these relatively large, continental-scale fluxes, there are a number of smaller fluxes that need to be known to calculate a "closed" carbon budget of the area (see below).

\subsection{Lateral fluxes to hydrosphere and trade}

River export of organic matter was taken from the COSCAT (Meybeck et al., 2006) dataset and provided in Table 1 for all rivers flowing out of the Russian territory. These numbers are obtained by multiplying discharge with DOC and POC and DIC concentration to obtain the final export fluxes. Note that this may introduce a bias if either the discharge or the concentration shows large temporal variability.

\subsection{Trade and wood export}

For trade, we use the approach and estimates based on Ciais et al. (2008). Wood export is taken from original Russian statistics and the FAOSTAT (http://faostat.fao.org/site/628/ default.aspx).

\subsection{Fire and insect outbreaks}

We use two estimates of vegetation fire emissions provided for 1998-2010. In the LEA we use (Shvidenko et al., 2011a) burnt areas defined using NOAA AVHRR from the modified algorithm described in Soja et al. (2004). Regional groundbased regressions were used to eliminate the bias in assessing areas. Carbon emissions were estimated based on Seiler and Crutzen (1980) using land cover characteristics and biophysical indicators from the hybrid land cover. The second estimate is based on the widely used GFED-3 data product (van der Werf et al., 2010). GFED-3 $\mathrm{CO}_{2}$ emissions are calculated by a revised version of the Carnegie-AmesStanford Approach (CASA) biogeochemical model and improved satellite-derived estimates of area burned, fire activity, and plant productivity to calculate fire emissions for the 1997-2009 period at a $0.5^{\circ}$ spatial resolution with a monthly time step. For November 2000 onwards, the GFED-3 estimates are based on burned area, active fire detections, and plant productivity from the MODerate resolution Imaging Spectroradiometer (MODIS) sensor. We extracted the data for the Russian territory.

Emissions caused by biotic impacts in forests (mostly insect outbreaks) were estimated based on an algorithm described in Shvidenko et al. (2010a).

\subsection{Land use change in LEA}

Two processes defined land use change in Russia after the 1990s, the crucial period after the decline of the Soviet system where large changes in the economy took place. These are taken into account in the LEA as follows. The first was the abandonment of agricultural land. Estimates of the total area of arable lands withdrawn form agricultural use given for the period 1990-2005 diverge widely ranging from 10.1 (FAOSTAT) to 34.0 Mha (Larionova et al., 2003) to $48.6 \mathrm{Mha}$ (as the difference between the total area of arable land by the State Land Account and cultivated land - 76.4 Mha in 2007, FSSS, 2009). The second was the increase of forested area of 31.3 Mha in 1990-2007 (Pan et al., 2011) due to encroachment of forests in abandoned agricultural land, decreasing harvest (FFS'RF, 2009) and zonal and altitudinal shift of forests likely due to climate change (e.g. Kharuk et al., 2010). In the next section we also provide a separate assessment of these effects based on model results and experimental evidence.

\section{Results}

We first present the results of four independent methods to calculate the Russian carbon balance. These include the Land Ecosystem Assessment, the result from eddy covariance estimates, presenting NEE and NEP, and the modeling results from the inversion schemes (NBP) and DGVMs (NBP). We then provide estimates of a number of smaller lateral fluxes that help us to calculate the final estimates of the Russian carbon balance. Finally, we calculate the Russian balance from a combination of these numbers in the last section.

\subsection{Land Ecosystem Assessment}

The results of the most recent assessment of carbon budget for Russian land by LEA are presented in Table 2 (Shvidenko et al., 2010a). The budget was based on the climatic conditions and disturbances of 2009. On average, this year is representative of the average climatic conditions since the 1970s, as it does not show any extreme behaviour (Roshydromet, 2011).

In 2009, terrestrial ecosystems of Russia generated a net flux of atmospheric $\mathrm{CO}_{2}$ to the land of $-0.76 \mathrm{PgC} \mathrm{yr}^{-1}$. Forests provide for about $90 \%$ of this sink. The $90 \%$ confidence interval (CI) error estimate (Shvidenko et al., 2010a), using Monte Carlo analysis, is also dominated by the error in the forest fluxes. The relative error of the NPP estimates is of the order of $5 \%$, while the estimate of heterotrophic

\footnotetext{
${ }^{1}$ RECCAP employs a sign convention where the net flux from atmosphere into the land is denoted as negative. For the common biological productivity, NPP, NEP, and NBP terms, we stick however to a positive sign if there is net growth. Respiration fluxes are positive as they represent a flux to the atmosphere.
} 
respiration carries a larger relative error $(\sim 10 \%)$. The sink density of Russian forests is close to the long-term carbon sink density of the EU-25 forests at $-75 \pm 20 \mathrm{~g} \mathrm{C} \mathrm{m}^{-2} \mathrm{yr}^{-1}$ (Luyssaert et al., 2010). Overall, these results are close to the previous estimates of the IIASA group for 2003-2008 (Shvidenko et al., 2010c), taking into account that they only estimated NBP for terrestrial ecosystems with consumption of agricultural products not included in the results. The two major biospheric gross fluxes, NPP and $\mathrm{H}_{\mathrm{SR}}$, are estimated at 4.76 and $3.46 \mathrm{Pg} \mathrm{C} \mathrm{yr}^{-1}$, respectively.

The spatial distribution of this carbon budget (for 2009) shows considerable variation, and substantial areas, particularly on permafrost and in disturbed forests, show both sink and source behaviour (Fig. 2).

The forest area increased during the past $18 \mathrm{yr}$ by $31.3 \mathrm{Mha}$ (to $845.6 \mathrm{Mha}$ in 2007). The average change in total organic carbon in forest ecosystems for this period was estimated at $259 \mathrm{Tg} \mathrm{C} \mathrm{yr}^{-1}$ for Asian Russia (giving a net atmosphereland flux of $-39 \mathrm{~g} \mathrm{C} \mathrm{m}^{-2} \mathrm{yr}^{-1}$ ) and $170{\mathrm{TgC} \mathrm{yr}^{-1}}^{\text {in } \mathrm{Eu}-}$ ropean Russia (creating a net atmosphere-land flux of $\left.-105 \mathrm{~g} \mathrm{C} \mathrm{m}^{-2} \mathrm{yr}^{-1}\right)$. This yields a value for the whole of Russia of $429 \mathrm{TgC} \mathrm{yr}^{-1}\left(-52 \mathrm{~g} \mathrm{C} \mathrm{m}^{-2} \mathrm{yr}^{-1}\right)$. Major contributions to this change were the increase of live biomass (mostly in the European part) and dead wood and on-ground litter (mostly in Asian Russia). The uncertainty of these estimates was estimated to be about $\pm 25 \%$ (CI 0.95) (Pan et al., 2011). We emphasize, however, that in that study the FAO definition of forest was used while all results from the LEA use the Russian definition. This causes a difference in the NBP for Russian land of about $15 \%$.

Changes in climate of the last two decades provoked substantial acceleration of vegetation fires in the Russian territory. Catastrophic (mega-) fires, enveloping large areas, can be of high severity and provide major impacts on ecosystems and landscapes. Piao et al. (2011) have observed a decline of spring and summer NDVI since 1997 after two decades of greening, and attributed this to climate trends. Over 19822005, Goetz et al. (2007) analyzed AVHRR vegetation indices and found increases in Northeast Siberia and decreases in the Yakutsk region, attributed to recent fire emissions. Severe impacts appear now to have become a typical feature of the current fire regime. Note that most fires are ignited by humans (Mollicone et al., 2006).

Shvidenko et al. (2011) reported the total burnt area in Russian territories in 1998-2010 to be 106.9 Mha or on average $8.23 \mathrm{Mha} \mathrm{yr}^{-1}$ with a substantial interannual variability, from 4.2 (1999) to 17.3 (2003) $\mathrm{Mha} \mathrm{yr}^{-1}$. Forestland comprises about two-thirds of this area. The estimated amount of vegetation carbon consumed by fires by the LEA model is on average $121.0 \mathrm{Tg} \mathrm{C} \mathrm{yr}^{-1}$, going from 50 (2000)

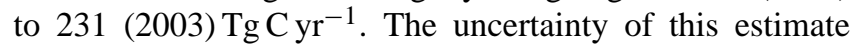
is around $\pm 9 \%$ for the area and $\pm 23 \%$ (CI 0.9 ) for the emissions. The emitted products of burning included $\mathrm{C}$ $\mathrm{CO}_{2}(84.6 \%), \mathrm{CO}(8.2 \%), \mathrm{CH}_{4}(1.1 \%)$, and $\mathrm{NMHC}(1.2 \%)$. Particulate matter accounted for $3.5 \%$, of which $\mathrm{PM}_{2.5}$ is
$1.2 \%$. The above estimate of the fire emission does not include decomposition of post-fire dieback.

These fire estimates are close to the results reported in GFED3 (van der Werf et al. 2010) - this study estimated the average burnt area in 1998-2010 at 9.17 $\mathrm{Mha} \mathrm{yr}^{-1}(+11.5 \%)$ and emissions of $137 \mathrm{Tg} \mathrm{Cyr}^{-1}(+13.2 \%)$. Figure 3 shows the monthly and annual pattern of carbon emissions due to fires for the two methods used. Noteworthy are the large emissions in 1997 and 2003. Overall, the average emission due to fires during 1998-2010 is estimated at 120$130 \mathrm{Tg} \mathrm{Cyr}^{-1}$, with an estimated uncertainty of $\sim 25 \%$ (van der Werf et al., 2010). Note from Fig. 3 that a variability of a factor 0.5 to 3 is estimated around this average value. Note also that fires have a C sink legacy: in central Russia, NDVI recovery after stand-replacing fires was calculated to occur in $13 \mathrm{yr}$ (Cuevas-Gonzalez et al., 2009). In absence of a regular forest biomass inventory, it is difficult to estimate the $\mathrm{C}$ sink of the area of re-growing forests on Russia. The latter is included as a part of the total sink of the forests.

Carbon emissions due to other environmental impacts and biotic disturbances were also taken into account. These apply to areas affected by insect and diseases, direct consumption of plant product biomass, decrease of NPP and post-disturbance dieback of forest. For areas that were disturbed or lost stability, decreasing NPP and increasing postdisturbance dieback were taken into account. The flux of $50.8 \mathrm{Tg} \mathrm{C} \mathrm{yr}^{-1}$ to the atmosphere for 2009 due to impacts of insect and diseases (Table 2) should be considered as a conservative estimate; for years with pandemic outbreaks of foliage-eating insects, such a flux could be substantially higher (e.g. for 2000-2001, when areas affected by Siberian silk worm in Siberia were estimated above $10 \mathrm{Mha}$ ) (FFS'RF, 2009).

Overall, agricultural land acts as a substantial sink in the LEA, including the response to abandonment since 1990. However, if consumption of the agricultural products is taken into account, substantial areas of arable land would become a net carbon source. In our budget we separately calculate the consumption at $170.4 \mathrm{Tg} \mathrm{C} \mathrm{yr}^{-1}$ (Table 2).

Wetlands are estimated as a relatively high net sink in 2009 $\left(-53.4 \mathrm{Tg} \mathrm{C} \mathrm{yr}^{-1}\right.$, Table 2). However, we have to take into account low carbon emissions due to moderate fires, particularly on wetlands in 2009 . On average, fire on wetlands provided $\sim 16 \%$ of all the fire emissions in 1998-2010. Note that in the $\mathrm{CH}_{4}$ budget the wetlands play a very important role (e.g. Petrescu et al., 2010).

Several land classes were estimated as a net C source open woodlands, burnt areas, grasses and shrubs (Table 2). Open woodlands are represented, to a significant extent, by forests disturbed by different agents, and grass and shrubs are mostly situated in the northern bioclimatic zones on permafrost with a high heterotrophic respiration due to warming during recent decades.

The results from the LEA above are limited strictly to the Russian territory. Reliable information on the carbon budgets 
Table 1. Estimates of carbon export (dissolved inorganic carbon (DIC), dissolved organic carbon (DOC), and particulate organic carbon(POC)) together with basins and estimated discharge. Basin delineation from Meybeck et al. (2006).

\begin{tabular}{|c|c|c|c|c|c|}
\hline COSCAT name & Principal basin & $\begin{array}{l}\text { Discharge } \\
\mathrm{km}^{3} \mathrm{yr}^{-1}\end{array}$ & $\begin{array}{l}\text { DIC flux } \\
\mathrm{Gg} \mathrm{yr}^{-1}\end{array}$ & $\begin{array}{r}\text { DOC flux } \\
\mathrm{Gg} \mathrm{yr}^{-1}\end{array}$ & $\begin{array}{r}\text { POC flux } \\
\mathrm{Gg} \mathrm{yr}^{-1}\end{array}$ \\
\hline West Kara Sea & Ob, Taz, Pur, Nadym & 878.63 & 2778.53 & 2967.01 & 1372.16 \\
\hline East Kara Sea & $\begin{array}{l}\text { Yenisei, Pyasina, } \\
\text { Taymyra, Lenivaya }\end{array}$ & 699.56 & 5480.98 & 2942.18 & 1215.88 \\
\hline West Laptev Sea & $\begin{array}{l}\text { Lena, Khatanga, } \\
\text { Olenek, Anabar }\end{array}$ & 583.45 & 6756.96 & 2457.63 & 1875.32 \\
\hline East Laptev Sea & $\begin{array}{l}\text { Yana, Omoloy, } \\
\text { Sellyakh }\end{array}$ & 36.39 & 157.26 & 163.81 & 127.27 \\
\hline East Siberian Sea & $\begin{array}{l}\text { Kolyma, Indigirka, } \\
\text { Alazeya, Pegtymel, } \\
\text { Khroma }\end{array}$ & 184.67 & 1003.13 & 967.23 & 482.79 \\
\hline New Siberia Plateau & no important rivers & 1.92 & 8.56 & 3.49 & 2.96 \\
\hline West Chukchi Sea & Rekuul, Amguema & 25.79 & 152.30 & 114.96 & 71.06 \\
\hline Anadyr Gulf & Anadyr & 65.07 & 404.48 & 275.63 & 165.31 \\
\hline West Aleutian Basin & No important rivers & 59.67 & 407.18 & 197.69 & 129.00 \\
\hline $\begin{array}{l}\text { South East } \\
\text { Kamchatka Coast }\end{array}$ & Kamchatka & 65.97 & 368.76 & 253.68 & 258.73 \\
\hline East Okhotsk Sea & Penzhina, Gizhiga & 116.46 & 687.89 & 636.41 & 289.60 \\
\hline $\begin{array}{l}\text { North West } \\
\text { Okhotsk Sea }\end{array}$ & Amur, Uda, Tugur & 432.57 & 2851.32 & 1897.72 & 1076.97 \\
\hline West Japan Sea & No important rivers & 84.27 & 912.70 & 473.39 & 500.13 \\
\hline Endhoreic areas & & 600 & 7940 & 2772 & 2772 \\
\hline Total & & & 29910 & 16123 & 10339 \\
\hline
\end{tabular}

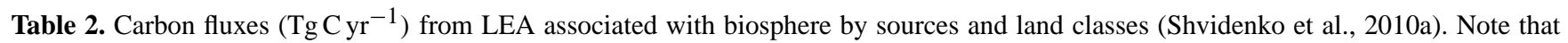
production fluxes such as NPP are positive by default when there is growth. All other fluxes in the RECCAP convention represent a flux from biosphere to atmosphere when positive. The balance is then calculated from NPP- $\mathrm{H}_{\mathrm{SR}}-\mathrm{DEC}$-Fire-Insect. The balance represents NBP of the LEA. $\mathrm{H}_{\mathrm{SR}}$ is heterotrophic soil respiration, DEC is disturbance.

\begin{tabular}{|c|c|c|c|c|c|c|c|c|}
\hline \multirow{2}{*}{$\begin{array}{l}\text { Land class and } \\
\text { processes }\end{array}$} & \multirow{2}{*}{$\begin{array}{l}\text { Area, } \\
\text { Mha }\end{array}$} & \multicolumn{7}{|c|}{ 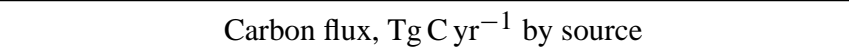 } \\
\hline & & NPP & $\mathrm{H}_{\mathrm{SR}}$ & DEC & Fire & Insect & Balance & $90 \% \mathrm{CI}$ \\
\hline Forest & 820.9 & 2610.2 & 1637.0 & $175.0 *$ & 55.5 & 50.8 & -691.9 & 175.3 \\
\hline Arable & 77.8 & 409.1 & 330.4 & & 0.4 & & -78.3 & 33.4 \\
\hline Hayfield & 24.0 & 109.1 & 79.5 & & 1.1 & & -28.5 & 9.2 \\
\hline Pasture & 68.0 & 330.8 & 212.0 & & 1.7 & & -117.1 & 26.2 \\
\hline Fallow & 19.0 & 21.2 & 16.7 & & 0.3 & & -4.2 & 2,1 \\
\hline Abandoned arable & 29.9 & 151.6 & 104.5 & & 1.0 & & -46.1 & 14.2 \\
\hline Wetland & 144.6 & 395.2 & 317.5 & 3.3 & 21.0 & & -53.4 & 35 \\
\hline Open woodland & 85.1 & 84.2 & 116.0 & 2.8 & 5.7 & & 40.3 & 12 \\
\hline Burnt area & 23.7 & 32.9 & 38.9 & 13.4 & 1.4 & & 20.8 & 4.7 \\
\hline Grass and shrubland & 315.7 & 618.8 & 611.4 & 13.2 & 9.2 & & 15.0 & 54.3 \\
\hline Interim water**** & -44.0 & & & & & & 11.8 & 1.5 \\
\hline $\begin{array}{l}\text { Consumption of } \\
\text { plant products }\end{array}$ & & & & & & & $170.4 * *$ & 35 \\
\hline Biosphere total & $1709.8 * * *$ & 4763.2 & 3463.8 & 207.7 & 97.2 & 50.8 & -761.3 & 195.9 \\
\hline
\end{tabular}




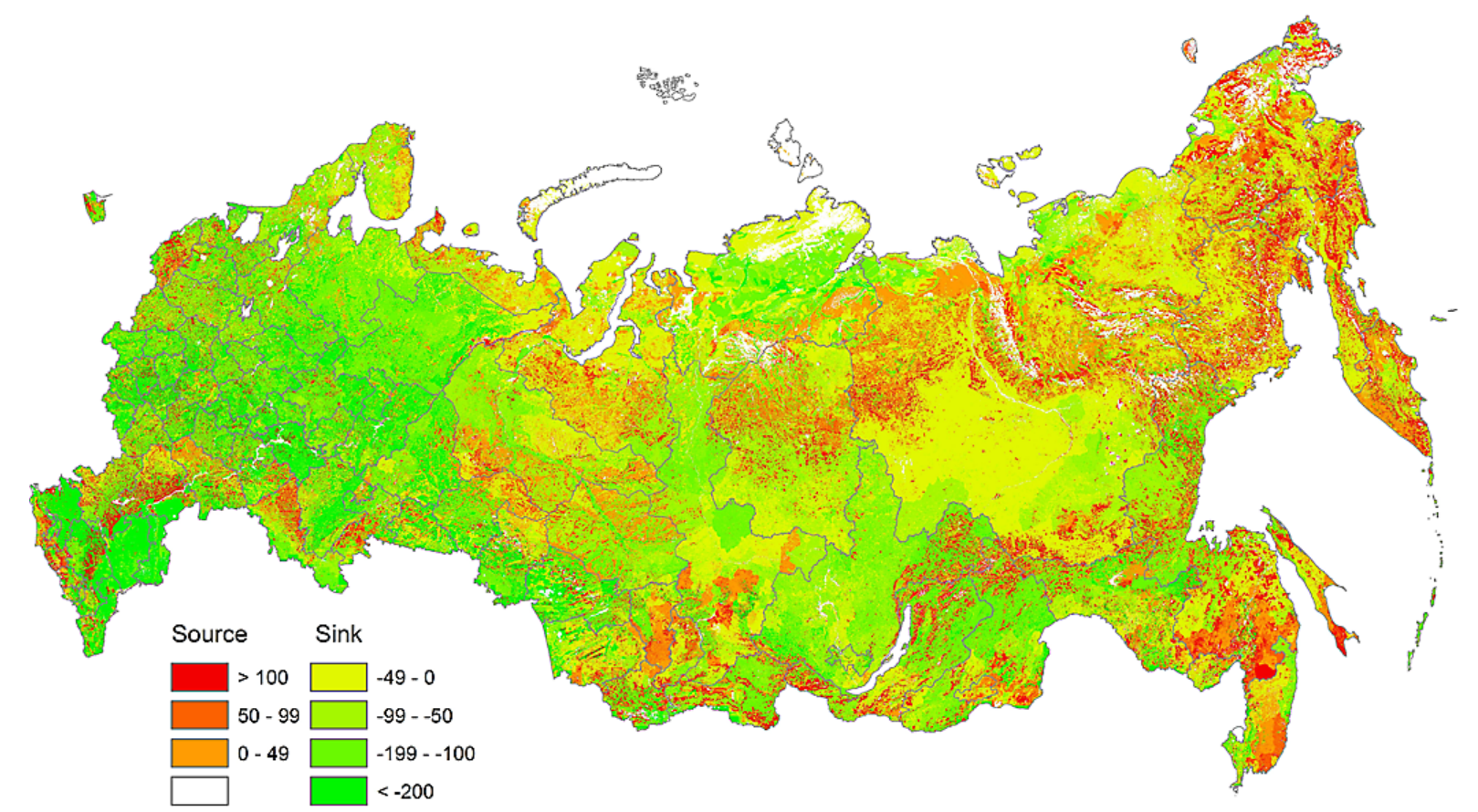

Fig. 2. NBP of Russian terrestrial ecosystems from the LEA system.

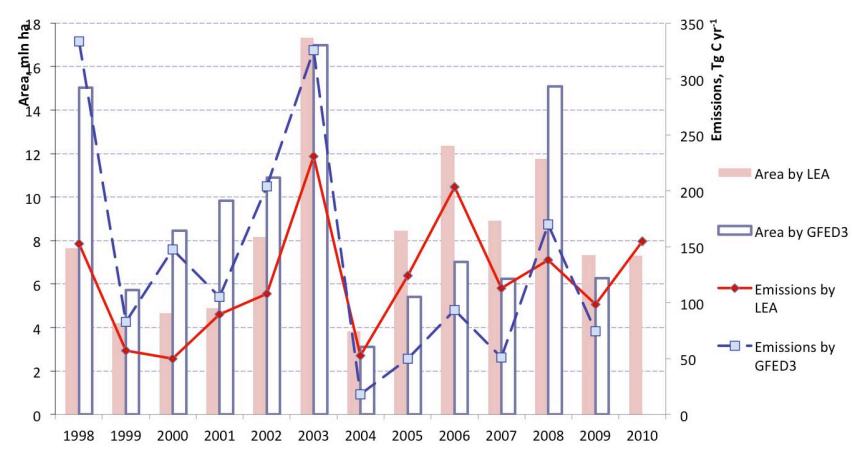

Fig. 3. Comparison of carbon emissions from vegetation fire in Russia from Shidenko et al. (2011a) between 1998-2010 with data of GFED3 (van de Werf et al., 2010).

of Ukraine, Belarus and Kazakhstan is scarce and often not complete. These countries have presented their second national communications to the UNFCCC Secretariat (available at unfccc.int/resource/docs/natc/). These countries show for forests a net land to atmosphere flux of $-3.6 \mathrm{Tg} \mathrm{C} \mathrm{yr}^{-1}$ in Belarus, $-15-18 \mathrm{Tg} \mathrm{C} \mathrm{yr}^{-1}$ in Ukraine and $-1.3{\mathrm{Tg} \mathrm{C} \mathrm{yr}^{-1}}^{-1}$ in Kazakhstan, on average, for the last $5 \mathrm{yr}$ of the reporting periods. However, emissions in agriculture and incompleteness, particularly of items of carbon disposal, virtually compensate the forest sink and change the total estimate of NBP for the region to within $1-2 \%$. The default IPCC methodologies used and the incompleteness of the accounts do not allow assessing the uncertainties involved. We therefore ex- clude the latter results in the overall bottom-up inventory results, but note that this likely causes small errors.

\subsection{Eddy covariance-based estimates of net ecosystem exchange}

Figure 4 shows the cumulative NEE for each of the 14 sites. Three clusters of sites may be distinguished: a wetland cluster where annual $\mathrm{CO}_{2}$ land to atmosphere fluxes occur of between -50 and $-90 \mathrm{~g} \mathrm{C} \mathrm{m}^{-2} \mathrm{yr}^{-1}$, a grassland cluster of between -125 and $-170 \mathrm{~g} \mathrm{C} \mathrm{m}^{-2} \mathrm{yr}^{-1}$, and a forest cluster with more variable NEE rates. Among 7 forest sites, 4 sites (Zotino pine and fir, Yakutsk pine and larix) show an uptake between -200 and $-300 \mathrm{~g} \mathrm{C} \mathrm{m}^{-2} \mathrm{yr}^{-1}$, and the 3 other (Tver dry and wet spruce and Zotino mixed forest) have an NEE between 0 and $-150 \mathrm{~g} \mathrm{C} \mathrm{m}^{-2} \mathrm{yr}^{-1}$. Consequently, all sites appear as net sinks of $\mathrm{CO}_{2}$, as expected for growing forests. The wet spruce forest site near Tver in European Russia is the only site that is on average a source of $\mathrm{CO}_{2}$ to the atmosphere, whereas it is $\mathrm{CO}_{2}$ neutral is some years. This may be explained by the mature successional stage of the forest, the large respiration from the boggy soil and the contribution to the flux of an area of windthrow in the area. It must be noted that the Tver sites are more sensitive than other sites to treatment of low turbulence data, probably because of the larger amount of winter measurements and the frequency of calms. The slope of the lines in Fig. 4 is a measure of the daily uptake rate. It is striking to see that, except for the bog sites near Tver and Zotino, the slopes compare well for a large number of sites in the middle of the growing season (growing season 


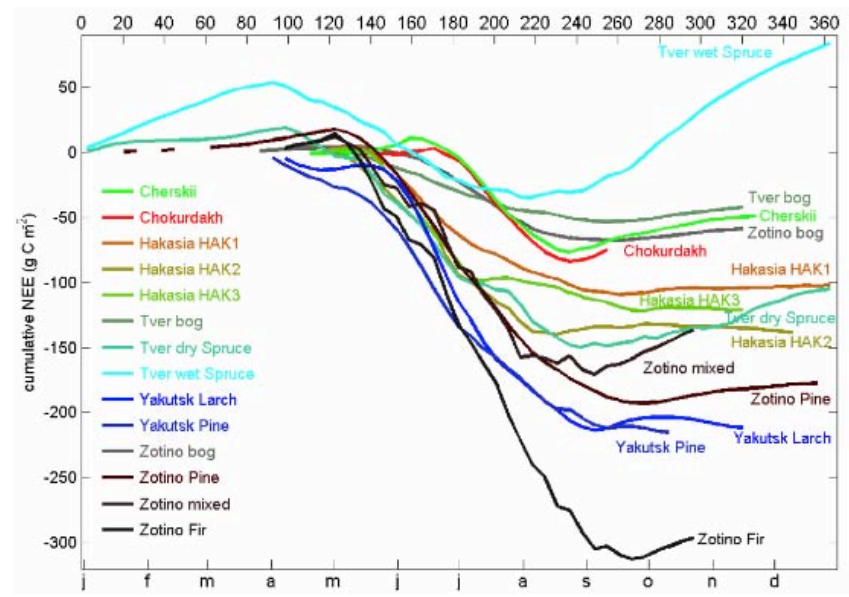

Fig. 4. Mean annual net uptake and release of carbon for a set of eddy covariance sites. For names of the sites, see text.

is loosely defined here as the season when carbon dioxide uptake occurs). The differences in annual $\mathrm{CO}_{2}$ uptake between sites appear to correlate well with the length of the growing season. This suggests that the length of the growing season does not only determine to a large part the variability of NEE between years, but also between sites. The length of the growing season varies from about 2 months at the tundra sites to about 7 months in Tver. The assumption of zero NEE before and after the measurement season is not supported by the Fig. 4 for some sites, most notably the fir and mixed forest near Zotino and the pine and larch forests near Yakutsk and the tundra site near Chokurdakh.

From the direct observations of NEE, NEP is calculated including corrections for neglected winter fluxes (Wang et al., 2011) and the use of an open path sensor that is sensitive to significant errors in conditions of cold temperatures. For forest, low and high estimates, which are based on the age class distribution of the forest and the sampling bias that nearly all eddy covariance observations exhibit, are taken in well-established, well-growing forests. Thus, NEE from flux observations is somewhat being biased towards a $\mathrm{CO}_{2}$ sink (Wang et al., 2011). The lower NEP estimate (66\% of the NEE based value) is most likely to be closer to reality than the higher one. Table 3 presents these values and the total scaled value based on relative area. The final estimate of the NEP of Russian ecosystems is a net biosphere to atmosphere flux of $-1.033{\mathrm{PgC} \mathrm{yr}^{-1}}^{-1}$, which compares with that obtained by the LEA technique $\left(940 \mathrm{Tg} \mathrm{Cyr}^{-1)}\right.$, when excluding the export of $\mathrm{C}$ from ecosystems to river headstreams and timber removal from forest. This is largely due to the fact that in both bottom-up estimates forest is the main contributor and those estimates are close. We note that the error estimate, as provided by the range in this case, is skewed towards the lower estimate of $-760 \mathrm{PgC} \mathrm{yr}^{-1}$ and is larger in absolute value that the $90 \% \mathrm{CI}$ interval error of the LEA.
Table 3 presents the final results of NEP estimated from the limited available set of eddy covariance towers across Russia. We present also a scaled-up estimate based on these observations. We note a number of uncertainties. First, the estimate is based on a limited number of sites that are considered representative of each biome. We realize that estimating the sink of the Russian biosphere from 14 eddy covariance sites is a rather grand assumption that should be treated with caution. However, since we are comparing several methods in this paper to estimate the overall Russian carbon balance, we believe our approach is justified within the limits of the assumptions and error estimates and that these sites are representative. The second issue relates to the estimate of land use change fluxes. To estimate the uncertainty associated with this, we present in Table 2 estimates from both the LEA system and the Global Land Cover estimates of land cover (GLC, 2003). For forests the estimates of NEP between LEA and flux tower upscaling are quite close; for tundra and wetland, however, large differences exist. This sensitivity of emissions to land cover classification was noted earlier by Petrescu et al. (2010) who identified the land cover estimates as one of the main uncertainties in estimating $\mathrm{CH}_{4}$ emissions. Karelin and Zamolodchikov (2008) have provided an assessment of NEE in Russian tundra on 11 sites also from eddy covariance data and came to an average NEE of $-4.9 \pm 17.4 \mathrm{~g} \mathrm{C} \mathrm{m}^{-2}$. This is close to neutral $\mathrm{CO}_{2}$ balance of tundra and is also rather different from our current estimate. Our current estimate is, however, close to that of LEA.

\subsection{Inverse model estimates}

We use the results of 12 different inversion models and extract the values for the Russian territory. In Fig. 5 we show the mean and the range (min, max) of the inversion schemes. Note that towards the end of the period, the number of models, as well as the number of observational stations used in the inversions, increases. Most of the model estimated net land-atmosphere $\mathrm{CO}_{2}$ flux, with subtracted fossil $\mathrm{CO}_{2}$ emissions, suggest a relatively stable sink of atmospheric $\mathrm{CO}_{2}$, while some others suggest a slowly increasing sink. For our analysis we use the mean atmosphere to land $\mathrm{CO}_{2}$ flux of the last $10 \mathrm{yr}$ at $-653 \mathrm{TgC}^{-1}$ for the period of 1998 2008, for which most of the models yield results (Table 4). This result is in line with published model results, which are available for NBP of boreal Asia, of $-630 \mathrm{Tg} \mathrm{C} \mathrm{yr}^{-1}$ for 1280 Mha (Maksyutov et al., 2003), $-580 \mathrm{Tg} \mathrm{C} \mathrm{yr}^{-1}$ (from an average of 17 inverse models, Gurney et al., 2003), and $-332 \mathrm{Tg} \mathrm{C} \mathrm{yr}^{-1}$ (Baker et al., 2006). Ciais et al. (2010), using 4 different inversions for the period 2000-2004, estimate a net biosphere to atmosphere flux of $\mathrm{CO}_{2}$ of about -600 to $-700 \mathrm{TgC}$, which also agrees well with our mean value. There is no uncertainty estimate attached to these numbers other than the range, which varies, if we exclude the GEOSTAT and MATCH outliers, in the present study from -390 to $-1305 \mathrm{Tg} \mathrm{C} \mathrm{yr}^{-} 1$. Chevalier et al. (2010) propagated the 
full error covariance matrix for a single inversion model and obtained over Russia an uncertainty of the order of $0.7 \mathrm{Pg} \mathrm{C} \mathrm{yr}^{-1}$ ( $1 \sigma$ Gaussian error). This is comparable in magnitude to our observed range.

We also show the interannual variability as estimated by the standard deviation of the yearly estimates from each model. This is reasonably consistent at around 200$250 \mathrm{Tg} \mathrm{C} \mathrm{yr}^{-1}$ ). While thus the exact magnitude of the Russian sink can vary, the balance of the evidence suggests a strong and consistent (i.e. small interannual variability) biosphere to atmosphere flux of around $-650 \mathrm{Tg} \mathrm{C} \mathrm{yr}^{-1}$.

\subsection{DGVMs}

The use of DGVMs at national level (even for such a large country as Russia) allows us in principle to study interannual variability and trends in GPP and respiration. They necessarily oversimplify the real land cover, and as such do not include some important land classes for Russia (e.g. bogs), often underestimate (or ignore) disturbances, lack forest age classes, and ignore harvest. As a rule, they also do not include features such as permafrost, thermokarst processes and do not yet adequately include impacts of disturbances.

Virtually all DGVMs of the RECCAP database show an increase in GPP over the whole period from 1920 to 2008 (Fig. 6). This is balanced by an equally increasing amount of respiration. The average NBP, averaged over the Russian territory for the last $20 \mathrm{yr}$ as estimated by these models, is stable and points to a small land to atmosphere flux of $-199 \mathrm{Tg} \mathrm{C} \mathrm{yr}^{-1}$; however, the variability between the models, as expressed by the range, is large and amounts to $100 \%$ of this value. The average of the DGVMs' NPP is very close to that of the LEA estimates; the heterotrophic respiration differs by about 0.5 to $1 \mathrm{Pg} \mathrm{C} \mathrm{yr}^{-1}$ depending on the period chosen, with the 1990-2008 estimate the largest.

\section{Smaller and lateral fluxes}

To be able to calculate the final carbon budget of Russia and compare the four basic approaches, we need some smaller and lateral fluxes to be calculated.

\subsection{River export}

The river export from Russian rivers to the coastal seas is taken from the COSCAT catchments database (Meybeck et al., 2006) that contains rivers exporting into the ocean (Table 1). The total summed outflow is $16.1 \mathrm{Tg} \mathrm{Cyr}^{-1}$ for dissolved (DOC) and $10.3 \mathrm{Tg} \mathrm{C} \mathrm{yr}^{-1}$ for particulate (POC) organic material. Total dissolved inorganic (DIC) material is 29.9 $\mathrm{Tg} \mathrm{C} \mathrm{yr}^{-1}$; this brings the total outflow of carbon to 56.4 $\mathrm{Tg} \mathrm{C} \mathrm{yr}^{-1}$. The majority of carbon export takes place into the coastal Arctic seas, with the main contributions com-

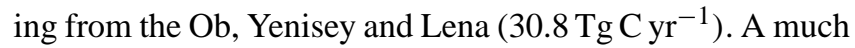
smaller export takes place from the rivers flowing into the
Japan and Ohkostk seas. It is important to note that the rivers draining into lakes and endorheic basins also present a noticeable outflow of carbon. Other published estimates are similar from 23.5 to $28.4 \mathrm{Tg} \mathrm{C} \mathrm{yr}^{-1}$ for DOC + POC and $33.8 \mathrm{Tg} \mathrm{C} \mathrm{yr}^{-1}$ for DIC delivered to the Arctic seas of Russia (Romankevich and Vetrov, 2001). The fate of this terrestrial carbon on the continental shelves is not examined in this study, but a significant fraction could be oxidized. Note also that recent results suggest that the outflow, as measured at the mouth of the rivers, is not necessarily equal to the input from the terrestrial ecosystems, and that during transport biogeochemical transforms may take place (Battin et al., 2009), which make substantial re-assessment of our estimates probable.

Based on aggregation of the available measurements of the Russian territories, Shvidenko et al. (2010c) reported the total lateral export of organic carbon from the catchments to the hydrosphere and lithosphere at $81 \pm 36 \mathrm{Tg} \mathrm{C} \mathrm{yr}^{-1}$, of which the export to the hydrosphere constitutes $61 \pm 31 \mathrm{Tg} \mathrm{C} \mathrm{yr}^{-1}$, comparable to our numbers, and the carbon accumulation on geochemical barriers of the lithosphere at $20 \pm 18 \mathrm{Tg} \mathrm{C} \mathrm{yr}^{-1}$. The export to the hydrosphere includes $\mathrm{C}$ fluxes to all rivers and numerous inland lakes. These estimates are in line with a recent global analysis (Alvarez-Cobelas et al., 2012).

\subsection{Forest products and wood export-import}

Official data of removal of wood from Russian forests is lowbiased due to substantial illegal harvest and only partial accounting of the rural consumption. The total removal due to all types of harvest is estimated at $51 \mathrm{Tg} \mathrm{C} \mathrm{yr}^{-1}$ for 20032010. Of the total removal, wood products export minus import was accounted at $21.1-1.1=20 \mathrm{Tg} \mathrm{C} \mathrm{yr}^{-1}$, with export substantially exceeding import (Shvidenko et al., 2010a). The carbon balance of wood product pools that eventually release $\mathrm{CO}_{2}$ back to atmosphere includes increases in the

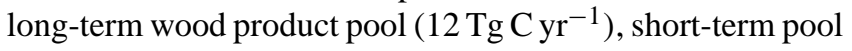
emissions including fuel wood, unused waste and residu-

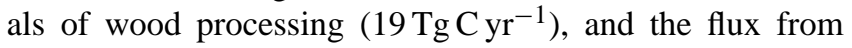
previously accumulated wood products. In Russia, the total amount of $\mathrm{C}$ stored in wood product pools decreases with time because the new inputs are less than the output, reflecting former decades of higher harvest. Import of food and other carbon products amount to $-18 \mathrm{Tg} \mathrm{C} \mathrm{yr}^{-1}$.

\subsection{Land use change and land abandonment since 1990}

Land use change is often estimated by a bookkeeping method based on Houghton et al. (2012). Unfortunately, after 1990 this database was not updated when considerable changes occurred after the fall of the economic Soviet system, and this presents a problem. Particularly, the area of arable lands in Russia has drastically decreased since the early 1990s when the Soviet economy collapsed. This land use change (LUC) is considered the largest of the 20th century in the 
Table 3. Estimated carbon uptake by biosphere calculated from eddy covariance observations. The values for specific forest and non-forest ecosystems are upscaled simply by estimating their areal extent. We give two estimates to identify uncertainty, but use eventually only the GLC estimate. This largely affects the non-forest biomes. The corrected NEE is obtained by accounting for age distribution of forests (M. J. van der Molen, personal communication, 2012).

\begin{tabular}{llllll}
\hline Land cover & $\begin{array}{l}\text { GLC area } \\
\text { in } 10^{12} \mathrm{~m}^{2}\end{array}$ & LEA & $\begin{array}{l}\text { Observed NEE } \\
\mathrm{g} \mathrm{C} \mathrm{m}^{-2} \mathrm{yr}^{-1}\end{array}$ & $\begin{array}{l}\text { Corrected NEE } \\
\mathrm{g} \mathrm{C} \mathrm{m}^{-2} \mathrm{yr}^{-1}\end{array}$ & $\begin{array}{l}\mathrm{NEP} \\
\mathrm{Tg} \mathrm{C} \mathrm{yr}^{-1}\end{array}$ \\
\hline Tundra & 3.9 & 2.3 & -58 & -30 & -119 \\
Wetlands & 0.5 & 1.5 & -52 & -63 & -31 \\
Grasslands & 1.1 & 0.7 & -107 & -74 & -80 \\
Agriculture & 1.6 & 2.2 & 0 & 0 & -0 \\
Larch & 3 & 2.8 & -200 & -151 & $-448(-296-475)$ \\
Pine & 1.4 & 1.3 & -197 & -149 & $-207(-98-157)$ \\
Spruce & 0.9 & 1.1 & 1 & 1 & -1 \\
Fir & 0.2 & 0.2 & -279 & -198 & $-37(-25-39)$ \\
Mixed/other & 2.9 & 4.3 & -119 & -38 & $-111(-73-118)$ \\
\hline $\begin{array}{l}\text { Area weighted } \\
\text { mean }\end{array}$ & 17.1 & 16.1 & & -60 & $-1033(-760-1097)$ \\
\hline
\end{tabular}

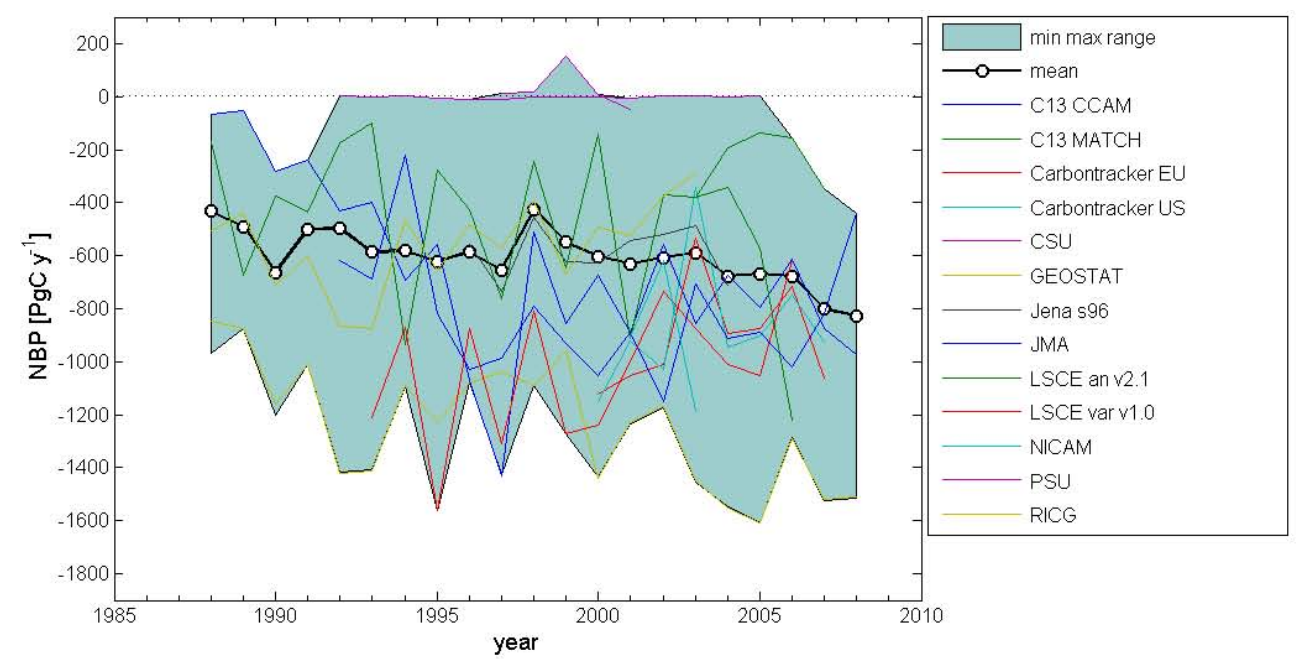

Fig. 5. Mean (black line) and range (grey area) of an ensemble of 12 inversion schemes for geographic Russia, Belarus and Ukraine. The range is determined by the maximum and minimum of the ensemble for each year.

Northern Hemisphere and is responsible for a substantial $\mathrm{CO}_{2}$ sink determined by the recovery of soil organic carbon that was previously depleted during intense cultivation (Guo and Gifford, 2002). Formerly ploughed lands were indeed found to increase the carbon content in the soil profile already after $4 \mathrm{yr}$ since the LUC, as a consequence of the encroachment of recovering grassland vegetation (Kurganova et al., 2008). Vuichard et al. (2008), using a model prescribed with FAO data for rates of cropland abandonment, estimated a mean sink of $-8 \mathrm{Tg} \mathrm{C} \mathrm{yr}^{-1}$ between 1991 and 2000 $\left(-47 \mathrm{~g} \mathrm{C} \mathrm{m}_{-2} \mathrm{yr}^{-1}\right)$. This is likely to represent an underestimate because regrowth of forest and shrubs over abandoned farmland was not modeled, and the study was restricted to southern European Russia, whereas significant abandonment took place after 2000 in Belarus, and after 1990 in Central Asia (e.g. Kazakhstan), see e.g. Henebry (2009).

According to field measurements of soil carbon content after LUC, carbon accumulation rates decline over time and are well described by a negative logarithmic model with the soil carbon pool tending asymptotically to a new equilibrium level (Kurganova et al., 2010a). Observed average increments in soil carbon are $132 \pm 21 \mathrm{~g} \mathrm{C} \mathrm{m}^{-2} \mathrm{yr}^{-1}$ (mean $\pm \mathrm{SE}$ ) within $15 \mathrm{yr}$ after land abandonment, $67 \pm 9 \mathrm{~g} \mathrm{C} \mathrm{m}^{-2} \mathrm{yr}^{-1}$ between

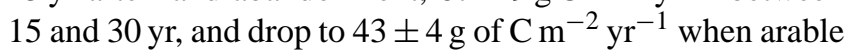
fields remain uncultivated for $>30 \mathrm{yr}$.

The magnitude of the sink varies also across different soil types of the Russian agricultural regions: mean carbon accumulation rates within the $0-20 \mathrm{~cm}$ soil layer during the first $15 \mathrm{yr}$ after abandonment range from $-66 \pm 24 \mathrm{~g} \mathrm{C} \mathrm{m}^{-2} \mathrm{yr}^{-1}$ 


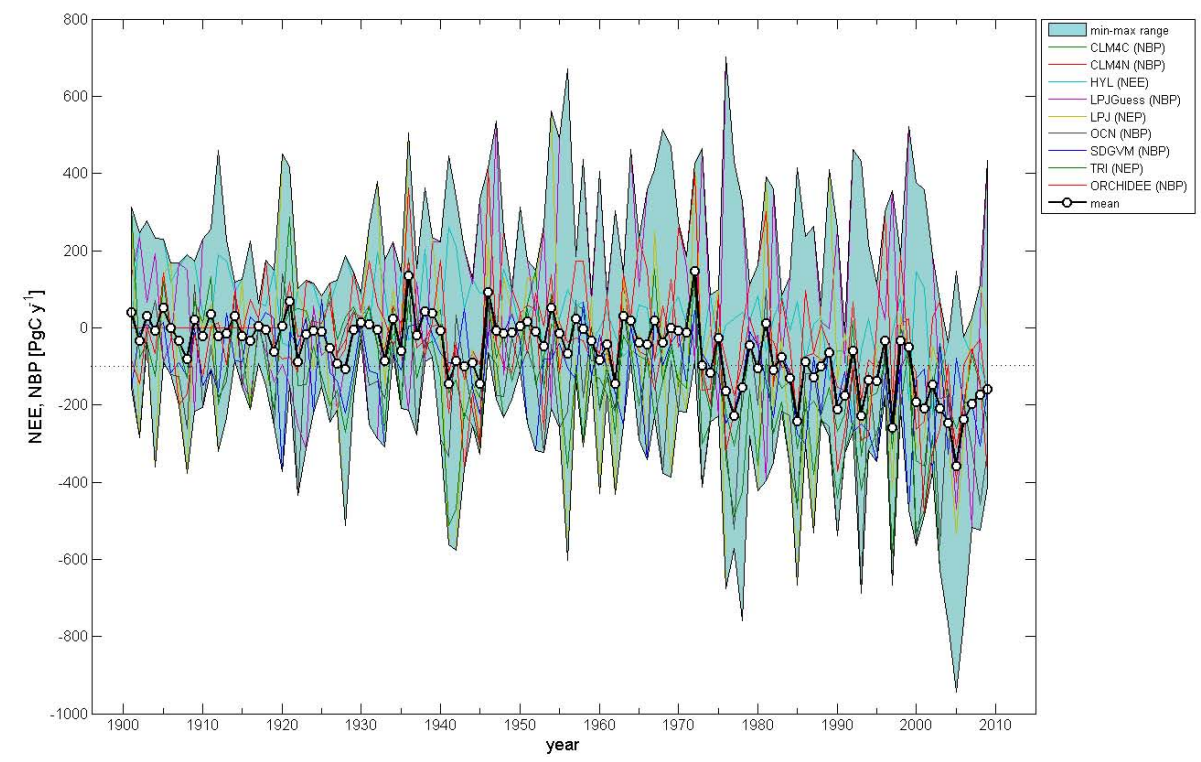

Fig. 6. Mean (black line) and range (grey area) of an ensemble of 8 dynamic global vegetation models (DGVMs) for geographic Russia, Belarus and Ukraine. The range is determined by the maximum and minimum of the ensemble for each year.

Table 4. Estimates of the average net biospheric carbon balance of Russia using 12 different inversion schemes (Gurney et al., 2012). Time period and interannual variability (IAV), expressed as the standard deviation, are also given.

\begin{tabular}{lllr}
\hline Inverse system & $\begin{array}{l}\text { Time } \\
\text { period }\end{array}$ & $\begin{array}{l}\text { Average net } \\
\text { biosphere to } \\
\text { atmosphere flux } \\
\left(\mathrm{Tg} \mathrm{C} \mathrm{yr}^{-1}\right)\end{array}$ & $\begin{array}{r}\text { IAV }\left(\sigma_{\mathrm{yr}}\right) \\
\left(\mathrm{Tg} \mathrm{C} \mathrm{yr}^{-1}\right)\end{array}$ \\
\hline C13 CCAM & $1992-2008$ & -820 & 210 \\
CSU & $2003-2006$ & -630 & 408 \\
CARBON- & $2000-2007$ & -907 & 199 \\
TRACKER-EU & & & 242 \\
CARBON- & $2000-2007$ & -872 & 76 \\
TRACKER-US & & & 237 \\
GEOSTAT & $1997-2001$ & 27 & 97 \\
JMA_2010 & $1985-2008$ & -1305 & 360 \\
LSCE_PEYLIN & $1996-2004$ & -587 & 260 \\
LSCE_4DVAR & $1988-2008$ & -895 & 259 \\
NICAM_NIWA & $1988-2007$ & -390 & 288 \\
NIES_PRABIR & $1993-2006$ & -992 & 4.75 \\
PSU & $2001-2003$ & -906 & 246 \\
MATCH & $1992-2005$ & -1.14 & \\
\hline Average & & -690 & \\
\hline
\end{tabular}

in Kastanozems to $-175 \pm 52 \mathrm{~g} \mathrm{C} \mathrm{m}^{-2} \mathrm{yr}^{-1}$ in Chernozems, with Albeluvisols and Phaeozems having similar intermediate rates $\left(-131 \pm 13\right.$ and $-134 \pm 36 \mathrm{~g} \mathrm{C} \mathrm{m}^{-2} \mathrm{yr}^{-1}$, respectively). However, as a result of the high variability in the rates of accumulation for each soil type, there are no significant differences among different geographical regions. Interestingly, estimates of the carbon balance of abandoned croplands on Chernozem soil in Hakassia at 5 and 10 years after LUC, made by eddy covariance measurements of ecosystem $\mathrm{CO}_{2}$ fluxes, show NEE rates of -216.2 and $-143.3 \mathrm{~g} \mathrm{C} \mathrm{m}^{-2} \mathrm{yr}^{-1}$ (Belleli, 2007), which agree with the results from soil inventories.

Estimates of total carbon sequestration in abandoned agricultural soils in Russia after 1990 differ widely by one order of magnitude ( -64 to $-694 \mathrm{Tg} \mathrm{C}$ ) because of differences in methodological approaches, limited amount of experimental data, time periods addressed, but mostly due to inconsistencies in the area of abandoned arable land among different statistical sources. On the assumption that the best estimate for the area of abandoned arable lands since 1990 in Russia is 30.2 Mha (FSSS, 2009; the remote sensing estimate consistent with the area of cultivated land is $34.9 \mathrm{Mha}$ in 2009, Shvidenko et al. 2010a), based on a large number of experimental data (Kurganova et al., 2010a), this indicates the total carbon accumulation in the first $20 \mathrm{~cm}$ depth of soil of former arable soils is $-548 \pm 35 \mathrm{Tg} C$ over the period 1990-2006. This yields an average rate of $C$ accumulation of $-34 \pm 2.2{\mathrm{Tg} \mathrm{C} \mathrm{yr}^{-1}}$ in the $1990-2006$ time window.

\section{4 $\mathrm{CH}_{4}$ fluxes}

The total anthropogenic emissions from Russia of $\mathrm{CH}_{4}$ from 2001 to 2005 are $19.5 \mathrm{Tg} \mathrm{Cyr}^{-1}$ (EC-JRC/PBL, EDGAR version 4.0, 2009), of these $15 \mathrm{TgC}^{-1}$ are due to the production of primary fuel, $1.5 \mathrm{Tg} \mathrm{C} \mathrm{yr}^{-1}$ due to enteric fermentation of livestock, and the rest made up of wasteland production and biomass burning. Wastewater treatment also adds

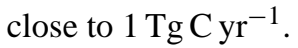


The net efflux of methane to the atmosphere caused by the biosphere within the Russian territory was estimated by a "semi-empirical" landscape ecosystem approach similar to the LEA as $16.2 \pm 3.9 \mathrm{Tg} \mathrm{Cyr}^{-1}$. Model estimates of $\mathrm{CH}_{4}$ fluxes for the Russian territory were derived by Petrescu et al. (2010) at 27.6 $\mathrm{Tg} \mathrm{C} \mathrm{yr}^{-1}$. Their estimate, however, refers only to boreal and arctic wetlands. A comparable estimate for boreal Asia, based on a combination of the biogenic MDM-TEM and the fire emissions, reported the annual release of around 41.5 $\mathrm{Tg} \mathrm{Cyr}^{-1}$ between 1997-2006, with most of the emissions ( $38 \mathrm{Tg} \mathrm{C} \mathrm{yr}^{-1}$ ) from the biogenic sources (McGuire et al., 2010).

Previous estimates of the biosphere's methane flux from Russia are very diverse - from $11 \mathrm{Tg} \mathrm{CH}_{4} \mathrm{yr}^{-1}$ (Harris et al., 1993) to $20 \mathrm{Tg} \mathrm{C} \mathrm{yr}^{-1}$ (Nilsson et al., 2000) to $30 \mathrm{Tg} \mathrm{C} \mathrm{yr}^{-1}$ (Zelenev, 1996) and even $39 \mathrm{Tg} \mathrm{C} \mathrm{yr}^{-1}$ (Rozanov, 1995). More recent regional estimates demonstrate more consistency in the estimated emission. While estimates of methane flux for West Siberian wetlands during the last two decades differed an order of magnitude (from 1.6 to above $20 \mathrm{Tg} \mathrm{C} \mathrm{yr}^{-1}$ ), estimates of the last several years vary around 3.2-3.5 $\mathrm{Tg} \mathrm{Cyr}^{-1}$ (e.g. Glagolev et al., 2010a, b), which is very close to the above LEA estimate for this re-

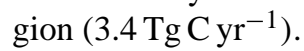

We take the net land to atmosphere flux of $\mathrm{CH}_{4}$ to be the anthropogenic flux of 19.5 plus the mean of the two estimates of the biospheric fluxes of 27.6 and $16.2 \mathrm{Tg} \mathrm{C} \mathrm{yr}^{-1}$ (21.9) yielding a flux of $41.4 \mathrm{TgC}^{-1}$. This also provides a range of 35.7 to $47.1 \mathrm{Tg} \mathrm{Cyr}^{-1}$.

\section{The carbon budget of Russia}

Our final bottom-up estimate of the Russian net land to atmosphere flux is based on the following equation:

$\mathrm{NBP}=\mathrm{NEP}-D-F_{\mathrm{LAT}}-F_{\left(\mathrm{CO}, \mathrm{CH}_{4}, \mathrm{VOC}\right)}$,

where $D$ represents the disturbance flux, comprised of fire, harvest, etc., the net lateral fluxes include export through rivers and the net flux as a result of trade and consumption. In Table 5 and Fig. 7, this procedure is shown in more detail. We start by bringing the LEA and Eddy Coveriance (EC) estimate to the same level, i.e. NEE. To achieve this, we need to calculate NEE from LEA by NEE $=\mathrm{NPP}-\mathrm{H}_{\mathrm{SR}}-\mathrm{DEC}$ (note that $\mathrm{H}_{\mathrm{SR}}$ contains only soil respiration; the remaining heterotrophic respiration and decay of wood, etc., are covered by the DEC term). The EC observations provide a direct measurement of this quantity. Subtracting fire and insect disturbance from the value of the LEA provide NBP; from the EC we use the GFED3 estimate and have to add in the sink that arose from land use change. This sink, amounting to

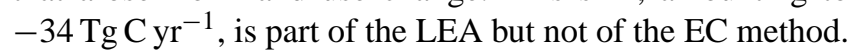
The resulting NBP (NEE minus disturbance) is now comparable to the flux seen by the inversions and calculated by the DGVMs. We further subtract the net lateral fluxes of wood,
Table 5. Calculation of the carbon budget of Russia starting from NEE (net ecosystem exchange) of the LEA and eddy covariance method. $D$ is disturbance. $F$ lateral fluxes. See text for further explanation.

\begin{tabular}{|c|c|c|c|c|}
\hline & \multicolumn{2}{|c|}{ 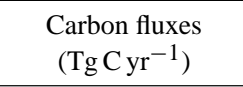 } & \multirow[b]{2}{*}{ Inversions } & \multirow[b]{2}{*}{ DGVN } \\
\hline & $\mathrm{EC}$ & LEA & & \\
\hline NEE & -1033 & -1079.2 & & \\
\hline Fire & 137 & 97.2 & & \\
\hline Insects & 50.8 & 50.8 & & \\
\hline LUC (agriculture) & -34 & & & \\
\hline Cons. plant prod. & 170.4 & 170.4 & & \\
\hline $\mathrm{NBP}=\mathrm{NEE}-D$ & -708.8 & -760.8 & -653 & -199 \\
\hline Wood net export & 20 & 20 & & \\
\hline Food net export & 18 & 18 & & \\
\hline Hydro/lithosphere & 56 & 61 & & \\
\hline $\mathrm{NBP}=\mathrm{NEE}-D-F$ & -614.8 & -661.8 & -554 & \\
\hline Fossil fuel & 454 & 454 & & \\
\hline $\mathrm{CH}_{4}$ & 41.4 & 41.4 & 41.4 & \\
\hline NEE- $D$ - $F$-Fossil Fuel & -119.4 & -166.4 & -58.6 & \\
\hline
\end{tabular}

food and hydrology from this number to obtain the final land to atmosphere flux of Russia for the EC, LEA and inverse models at $-614.8,-666.8$ and $-559 \mathrm{Tg} \mathrm{C} \mathrm{yr}^{-1}$, respectively. With an estimated $454 \mathrm{Tg} \mathrm{C}$ of fossil fuel per year (UNFCCC, Shvidenko et al., 2011), this leaves a net atmosphere

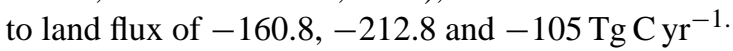

The DGVM results suggest a much smaller NBP than the other three methods. This is most probably related to the substantially higher estimate of heterotrophic respiration in the DGVMs compared to the other methods (see also discussion). We therefore exclude the DGVM result in the calculation of the final carbon budget.

For the LEA the estimated error in NBP is based on Table 2 and assuming the component errors (not shown) are Gaussian by nature and independent. This brings the error $(90 \% \mathrm{CI})$ in the NBP estimate to $195.8 \mathrm{Tg} \mathrm{C} \mathrm{yr}^{-1}$. The range in $\mathrm{EC}$ methods (Table 3 ) yields the final estimated range of NBP to -342 to $-687 \mathrm{Tg} \mathrm{C} \mathrm{yr}^{-1}$. For the model ensembles we also use the range. For the inverse methods the range would be -350 to $-1350 \mathrm{Tg} \mathrm{C} \mathrm{yr}^{-1}$. It is noteworthy that the DGVM estimate is considerably lower than any of the means or the lowest estimate of the range. The range in DGVM NBP estimates is -15.3 to $-345 \mathrm{Tg} \mathrm{C} \mathrm{yr}^{-1}$.

A realistic upper bound would thus be around $-342 \mathrm{Tg} \mathrm{C} \mathrm{yr}^{-1}$ from the EC method (and close to the LEA and inverse upper bound), with a lower range at $-1350 \mathrm{Tg} \mathrm{C} \mathrm{yr}^{-1}$ from the inversions, and around an average of $-613.5 \mathrm{Tg} \mathrm{C} \mathrm{yr}^{-1}$ from the three methods.

\section{Discussion}

The bottom-up, Land Ecosystem Assessment, eddy covariance upscaling and inverse modeling present rather 


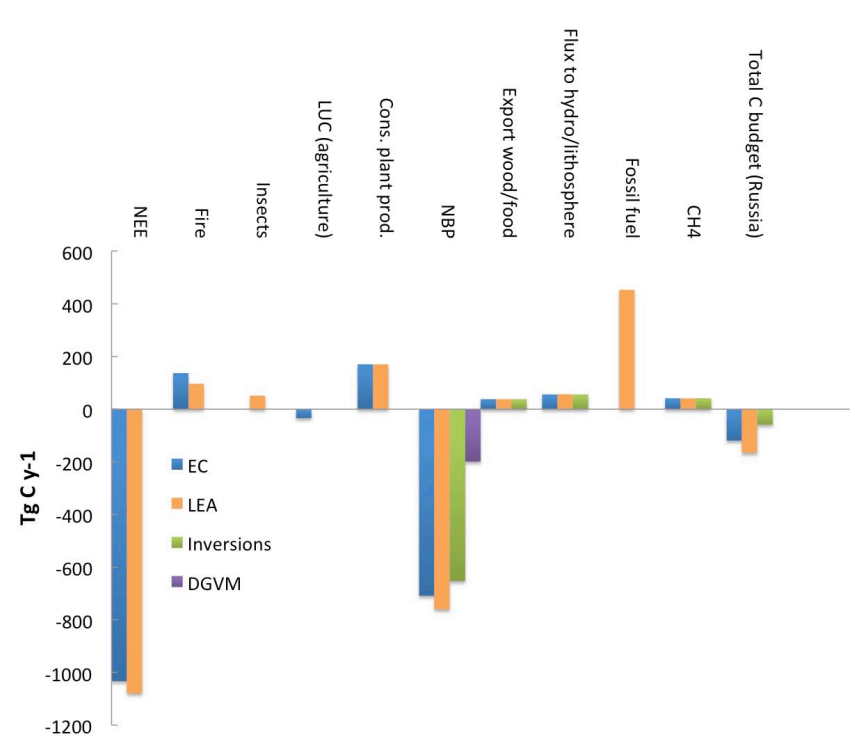

Fig. 7. The carbon balance components of Russia. The origin of the numbers used is described in the text.

consistent results. The terrestrial ecosystems of Russia provided during the last decades a net biosphere to atmosphere flux of around $-0.6 \mathrm{Pg} \mathrm{C} \mathrm{yr}^{-1}$, and forests were responsible for $90-95 \%$ of this value. Interannual variability of NBP is driven largely by seasonal weather, but is not extremely large in absolute terms, while locally regimes of natural disturbances, mostly fire and insect outbreaks, may cause substantial carbon losses.

Previously reported estimates of NPP range from 2.75 $\mathrm{Pg} \mathrm{Cyr}^{-1}$ (Filipchuk and Moiseev, 2003) for $\sim 2000$, to averages of $4.35 \mathrm{Pg} \mathrm{C} \mathrm{yr}^{-1}$ for 1988-1992 (Nilsson et al., 2003) and 4.73 $\mathrm{Pg} \mathrm{Cyr}^{-1}$ for 1996-2002 (Zavarzin, 2007) to $5.1 \pm 0.36 \mathrm{Pg} \mathrm{Cyr}^{-1}$ (Shvidenko et al., 2010c). Several other studies, using the chlorophyll index method, reported NPP in limits of $\pm 10 \%$ to the LEA estimate (Zavarzin, 2007). Our DGVM estimate for NPP is within this range with 4.07 and $4.7 \mathrm{Pg} \mathrm{Cyr}^{-1}$ for the earlier part of the 20th century and the last $20 \mathrm{yr}$, while the LEA estimates a value of $4.8 \mathrm{Pg} \mathrm{C} \mathrm{yr}^{-1}$. However, for the DGVMs heterotrophic respiration rates push the NEP far below the values calculated by the LEA. This was noted earlier by Quegan et al. (2010) for mid Siberia.

Kurganova (2003) estimated soil respiration to amount to 5.67, 2.78 and $2.89 \mathrm{PgC} \mathrm{yr}^{-1}$ for the total soil respiration and its heterotrophic $\left(\mathrm{H}_{\mathrm{RS}}\right)$ and autotrophic parts, respectively. She used direct measurements and an upscaling procedure. Schepaschenko et al. (2011b, 2012b) used land use and ecosystem type, bioclimatic zone, climatic conditions of individual years and NPP on soil respiration, and estimated soil heterotrophic respiration of Russian lands at $3.47 \mathrm{Pg} \mathrm{C} \mathrm{yr}^{-1}$. This is $\sim 25 \%$ more than the estimate by Kurganova (2003). There are a very few estimates of $\mathrm{CO}_{2}$ emissions to the atmosphere caused by the decomposition of dead wood (mostly in forests) in the range of $0.23-0.26 \mathrm{Pg} \mathrm{Cyr}^{-1}$ (Zavarzin, 2007; Shvidenko et al., 2010c). The DGVMs calculate a heterotrophic respiration rate of 4 and $4.5 \mathrm{Pg} \mathrm{C} \mathrm{yr}^{-1}$. This is considerably larger than any of the other estimates. We conclude that a large part of the uncertainty in the calculation of NEP and subsequently NBP, resides in the precise calculation of heterotrophic respiration.

The Land Ecosystem Assessment is a detailed, spatially explicit carbon account for the Russian region (Shvidenko et al., 2010a,b). While the country as a whole served as a net carbon sink, the LEA also finds that substantial areas are neutral or act as a relatively small carbon source. These areas are mostly confined to permafrost territories. This may be an indication that substantial areas at high latitudes may switch from sink to source as a result of regional warming (Hayes et al., 2011). However, the fire emissions in these studies are substantially higher than the empirical estimates (Van der Werf et al., 2010; Shvidenko et al., 2011). Note that McGuire et al. (2012) find a different tendency, albeit not with the complete current set of DGVMs. It is the correct description of the relative temperature sensitivity to photosynthesis and respiration that in the first instance produces the climate sensitivity of the high latitude carbon fluxes.

Quegan et al. (2011) use a similar approach as in the current study to estimate the carbon budget of central Siberia. They find an average biosphere to atmosphere flux of $-27.5 \pm 7.2 \mathrm{~g} \mathrm{C} \mathrm{m}^{-2} \mathrm{yr}^{-1}$, which corresponds to about $-470 \mathrm{Tg} \mathrm{C} \mathrm{yr}^{-1}$ if extrapolated to the Russian territory of $17.1 \times 10^{12} \mathrm{~m}^{2}$ (Table 2). This is remarkably close. Zavarzin (2007), Kurganova et al. (2010), and Filipchuk and Moiseev (2010) also report rather consistent results in the estimation of the accumulated NBP of the country's terrestrial ecosystems or individual classes, such as forests and agriculture. However, the major carbon fluxes like NPP, $\mathrm{H}_{\mathrm{SR}}$ and particularly fluxes caused by disturbances differ in these studies by up to factor of 3-4 due to different inputs, completeness and reliability of the accounting methodologies. As an example, estimates of forest NPP were $204 \mathrm{~g} \mathrm{C} \mathrm{m}^{-2} \mathrm{yr}^{-1}$ (Filipchuk and Moiseev, 2003) to $275 \mathrm{~g} \mathrm{C} \mathrm{m}^{-2} \mathrm{yr}^{-1}$ (Zamolodchikov and Utkin, 2000) and even to $614 \mathrm{~g} \mathrm{C} \mathrm{m}^{-2} \mathrm{yr}^{-1}$ (Gower et al., 2001). Importantly, the uncertainties of these latter estimates are not known.

Lack of knowledge and insufficient empirical data are among the important reasons that contribute to uncertainties of the results. For instance, it has been shown that assessment of forest NPP based on field measurements leads to biased conclusions because practically all measurements in situ (made in Russia by destructive methods) are not able to account for some important components (e.g. carbon turnover of fine roots, root exudates, VOC). Similarly, uncertainty of upscaled eddy covariance data cannot be assessed by formal methods due to the small amount of measured sites. However, these estimates do generate a "probable space" for the net ecosystem exchange. Similarly, inversions rely on often poorly defined a priori values and sparse observing stations. 
The wide range around our final average is a clear expression of this uncertainty.

The set of inverse models supplied important top-down information for verification. Our analysis shows almost identical results for the landscape-based approach, the eddy covariance approach and the average of the inverse modeling schemes. While these agreements may be fortuitous, the fact that most of the uptake is achieved by Russian forest, and the results of the LEA and eddy covariance agree in that respect, gives further confidence in these. The difference in range in the $\mathrm{EC}\left(0.33 \mathrm{Pg} \mathrm{Cyr}^{-1}\right)$ and inverse models (close to $1 \mathrm{Pg} \mathrm{C} \mathrm{yr}^{-1}$ ), as well as the estimated $90 \%$ CI uncertainty of the LEA $\left(0.2 \mathrm{PgC} \mathrm{yr}^{-1}\right)$, is large. Our high boundary estimate is $-342 \mathrm{Tg} \mathrm{C} \mathrm{yr}^{-1}$ from the EC method (and close to the LEA and inverse upper bound), with a lower boundary estimate at $-1350 \mathrm{Tg} \mathrm{C} \mathrm{yr}^{-1}$ from the inversions around an average of $-613.5 \mathrm{Tg} \mathrm{Cyr}^{-1}$. The DGVM estimate is well outside this range and requires further investigation as to its precise causes, the estimation of heterotrophic respiration being one of the prime suspects.

\section{Supplementary material related to this article is available online at: http://www.biogeosciences.net/9/ 5323/2012/bg-9-5323-2012-supplement.pdf.}

Acknowledgements. The authors would like to acknowledge the inspiration of the Global Carbon Project's RECCAP team that laid the basis for the present work. A. J. D. and T. C. acknowledge partial support from the EU FP7 Coordination Action on Carbon Observing System (COCOS, grant agreement no. 212196 and the Operational Global Carbon Observing System (GEOCARBON, grant agreement no: 283080). A. S. and D. S. acknowledge support from European Union Grants FP7-212535 (Project CC-TAME), FP7244122 (GHG-Europe), FP7-283080 (GEO-Carbon) and by the Global Environmental Forum, Japan (Project GEF-2).

E.-D. S., N. T. and A. J. D. acknowledge support from the Russian "Megagrant" 11.G34.31.0014 from 30 November 2010 to E.-D. Schulze by the Russian Federation and the Siberian Federal University to support research projects by leading scientists at Russian Institutions of higher education.

Edited by: J. Canadell

\section{References}

Alvarez-Cobelas, M., Angeler, D. G., Sanchez-Carrillo, S., and Almendros, G.: A worldwide view of organic carbon export from catchments, Biogeochemistry, 107, 275-293, 2012.

Battin, T. J., Luyssaert, S. L., Kaplan, L. A., Aufdenkampe, A. K., Richter, A., and Tranvik, L. J.: The boundless carbon cycle, Nat. Geosci., 2, 508-600, 2009.
Baker, D. F., Law, R. M., Gurney, K. R., Rayner, P., Peylin, P., Denning, A. S., Bousquet, P., Bruhwiler, L., Chen, Y.-H., Ciais, P., Fung, I. Y., Heimann, M., John, J., Maki, T., Maksyutov, S., Masarie, K., Prather, M., Pak, B., Taguchi, S., and Zhu, Z.: TransCom 3 inversion intercomparison: Impact of transport model errors on the interannual variability of regional $\mathrm{CO}_{2}$ fluxes, 1988-2003, Global Biogeochem. Cy., 20, GB1002, doi:10.1029/2004GB002439, 2006.

Beer, C., Lucht, W., Schmullius, C., and Shvidenko, A.: A small net carbon dioxide uptake by Russian forests during 1961-1999, Geophys. Res. Lett., 33, L15403, doi:10.1029/2006GL026919, 2006.

Belelli Marchesini, L.: Analyses of the carbon cycle of steppe and old field ecosystems of Central Asia, Ph.D. thesis, University of Tuscia, Viterbo, Italy, 227 pp., 2007.

Bousquet, P., Ciais, P., Peylin, P., Ramonet, M., and Monfray, P.: Inverse modeling of annual atmospheric $\mathrm{CO}_{2}$ sources and sinks 1, Method and control inversion, J. Geophys. Res., 104, 2616126178, doi:10.1029/1999JD900342, 1999.

Canadell, J. G., Ciais, P., Gurney, K., Le Quéré, C., Piao, S., Raupach, M. R., and Sabine, C. L.: An international effort to quantify regional carbon fluxes, EOS, 92, 81-82, 2011.

Chapin III, F. S., Sturm, M., Serreze, M., CMcFadden, J. P., Key, J. R., Lloyd, A. H., McGuire, A. D., Rupp, T. S.. Lynch, A. H., Schimel, J. P., Beringer, J., Chapman, W., L Epstein, H. E., Euskirchen, E. S., Hinzman, L. D., Jia, G., Ping, C.-L., Tape, K. D., Thompson, C. D. C., Walker, D. A., and Welker, J. M.: Role of Land-Surface Changes in Arctic Summer Warming, Science, 310, 657-660, doi:10.1126/science.1117368, 2005.

Chen Jing, M., Chen, B., Higuchi, K., Liu, J., Chan, D., Worthy, D., Tans, P., and Black, A.: Boreal ecosystems sequestered more carbon in warmer years, Geophys. Res. Lett., 33, L10803, doi:10.1029/2006GL025919, 2006.

Chevallier, F., Ciais, P., Conway, T. J., Aalto, T., Anderson, B. E., Bousquet, P., Brunke, E. G., Ciattaglia, L., Esaki, Y., Fröhlich, M., Gomez, A., Gomez-Pelaez, A. J., Haszpra, L., Krummel, P. B., Langenfelds, R. L., Leuenberger, M., Machida, T., Maignani, F., Matsueda, H., Morguí, J. A., Mukai, H., Nakazawa, T., Peylin, P., Ramonet, M., Rivier, L., Sawa, Y., Schmidt, M., Steele, L. P., Vay, S. A., Vermeulen, A. T., Wofsy, S., and Worthy, D.: $\mathrm{CO}_{2}$ surface fluxes at grid point scale estimated from a global 21 year reanalysis of atmospheric measurements, J. Geophys. Res., 115, D21307, doi:10.1029/2010JD013887, 2010.

Ciais, P., Borges, A. V., Abril, G., Meybeck, M., Folberth, G., Hauglustaine, D., and Janssens, I. A.: The impact of lateral carbon fluxes on the European carbon balance, Biogeosciences, 5, 1259-1271, doi:10.5194/bg-5-1259-2008, 2008.

Ciais, P., Canadell, J. G., Luyssaert, S., Chevallier, F., Shvidenko, A., Poussi, Z., Jonas, M., Peylin, P., King, A. W., Schulze, E.D., Piao, S. L., Rodenbeck, C., Peters, W., and Breon, F. M.: Can we reconcile atmospheric estimates of Northern terrestrial carbon sink with land-based accounting? Curr. Opin. Environ. Sustain., 2, 225-230, doi:10.1016/j.cosust.2010.06.008, 2010.

Cuevas-Gonzalez, M., Gerard, F., Baltzer, H., and Riano, D.: Analysing forest recovery after wildfire disturbance in boreal Siberia using remotely sensed vegetation indices, Glob. Change Biol., 15, 561-577, 2009.

European Commission, Joint Research Centre (JRC)/Netherlands Environmental Assessment Agency (PBL): Emission Database 
for Global Atmospheric Research (EDGAR), release version 4.0., avalable at: http://edgar.jrc.ec.europa.eu, FAOSTAT, available at: http://faostat.fao.org/site/418/default.aspx, 2009.

FFS'RF: Major indicators of forest management in 1988, 19922008, Federal Service of Forest Management of the RF, Moscow, 221 pp., 2009 (in Russian).

Filipchuk, A. N. and Moiseev, B. N.: Assessment of atmospheric carbon uptake by vegetation cover in Russia, World Climate Conference, 29 September-3 October, Moscow, Russia, 503 pp., 2003.

Filipchuk, A. N. and Moiseev, B. I.: Calculation of the net annual increment of carbon according to the State forest register data. Proceedings of the International Conference on Environmental Observations, Modeling and Information Systems ENVIROMIS2010, 5-11 July 2010, Tomsk, Russia, 69-70, 2010.

FSSS: Agriculture statistics. Federal State Statistics Service, available at: http://www.gks.ru/doc_2009/bul_dr/pos_val_uroj09.zip (last access: July 2010), 2009.

Glagolev, M. V., Sirin, A. A., Lapshina, E. D., and Filippov, I. V.: Study of fluxes of carbon contained gases in wetland ecosystems of West Siberia. Bulletin of the Tomsk State Polytechnic University, Tovsk, Russia, 3, 120-127, 2010a (in Russian).

Glagolev, M. V., Kleptsova, I. E., Filippov, I. V., Kazantsev, V. S., Machida, T., and Maksyutov, S.: Methane emissions from subtaiga mires of Western Siberia: the Standard Model Bc5, Moscow Univ. Soil Sci. Bull., 65, 86-93, 2010b.

Global Land Cover 2000 database: European Commission, Joint Research Centre, available at: http://bioval.jrc.ec.europa.eu/ products/glc2000/glc2000.php, 2003.

Goetz, S. J., Mack, M. C., Gurney, K. R., Randerson, J. T., and Houghton, R. A.: Ecosystem responses to recent climate change and fire disturbance at northern high latitudes: observations and model results contrasting northern Eurasia and North America, Environ. Res. Lett., 2, 045031 doi:10.1088/17489326/2/4/045031, 2007.

Gower, S. T., Krankina, O. N., Olson, R. J., Apps, M. J., Linder, S., and Wang, C.: Net primary production and carbon allocation patterns of boreal forest ecosystems, Ecol. Appl., 11, 1395-1411, 2001.

Guo, L. B. and Gifford, R. M.: Soil carbon stock and land use change: a meta analysis, Glob. Change Biol. 8, 345-360, 2002.

Gurney, K. R., Law, R. M., Denning, A. S., Rayner, P. J., Baker, D. Bousquet, P., Bruhwilerk, L., Chen Y.-H., Ciais, P., Songmiao Fan, S., Fung, I. Y., Gloor, M., Heimann, M., Higuchi, K., John, J., Maki, T., Maksyutov, S., Masariek, K., Peylin, P., Pratherkk, M., Pak, B. C., Randerson, J., Sarmiento, J., Taguchi, S., Takahashi, T., and Yuen, C.-W.: Towards robust regional estimates of $\mathrm{CO}_{2}$ sources and sinks using atmospheric transport models, Nature, 415, 626-630, 2002.

Gurney, K. R., Law, R. M., Denning, A. S., Rayner, P. J., Baker, D., Bousquet, P., Bruhwilerk, L., Chen Y.-H., Ciais, P., Songmiao Fan, S., Fung, I. Y., Gloor, M., Heimann, M., Higuchi, K., John, J., Kowalczyck, E., Maki, T., Maksyutov, S., Masariek, K., Peylin, P., Pratherkk, M., Pak, B. C., Randerson, J., Sarmiento, J., Taguchi, S., Takahashi, T., and Yuen, C.-W.: TransCom $3 \mathrm{CO}_{2}$ inversion intercomparison: 1. Annual mean control results and sensitivity to transport and prior flux information, Tellus B, 55, 555-579, 2003.
Harris, R. K., Bartlett, S., Frolking, S., and Crill, P.: Methane emissions from northern high latitude wetlands, in: Biogeochemistry of Global Change: Radiatively Active Trace Gases, edited by: Oremland, R. S., New-York, Chapman \& Hall, 449-486, 1993.

Hayes, D. J., McGuire, A. D., Kicklighter, D. W., Gurney, K. R, Burnside, T. J., and Melillo, J. M.: Is the northern high-latitude $\mathrm{CO}_{2}$ sink weakening?, Global Biogeochem. Cy., 25, GB3018, doi:10.1029/2010GB003813, 2011.

Henebry, G. M.: Carbon in idle croplands, Nature, 457, 1089-1090, 2009.

Houghton, R. A., van der Werf, G. R., DeFries, R. S., Hansen, M. C., House, J. I., Le Quéré, C., Pongratz, J., and Ramankutty, N.: Chapter G2 Carbon emissions from land use and land-cover change, Biogeosciences Discuss., 9, 835-878, doi:10.5194/bgd9-835-2012, 2012.

International Arctic Science Committee: Topic Editor: Hanson, H., "Arctic Climate - Past and Present", in: Encyclopedia of Earth, edited by: Cutler, J., Cleveland, Washington, DC, Environmental Information Coalition, National Council for Science and the Environment, First published in the Encyclopedia of Earth 9 February 2010, available at: http://www.eoearth.org/ article/Arctic_Climate_-_Past_and_Present, 2010.

Karelin, D. V. and Zamolodchikov, D. G.: Carbon exchange in cryogenic ecosystems, Nauka, Moscow, 344 pp., 2008 (in Russian).

Kharuk, V. I., Im, S. T., and Dvinskaya, M. L: Forest-tundra ecotone response to climate change in the Western Sayan Mountains, Siberia, Scand. J. Forest Res., 25, 224-233, 2010.

Kurganova, I. N.: Carbon dioxide emission from soils of Russian terrestrial ecosystems. Interim Report, IR-02-070, IIASA, Laxenburg, Austria, 64 pp., 2003.

Kurganova, I. N., Lopes de Gerenyu, V. O., Myakshina, T. N., Sapronov, D. V., Lichko, V. I., and Yermolaev, A. M.: Changes in the carbon stocks of former croplands in Russia, Agric. Sci., 15, 10-15, 2008.

Kurganova, I. N., Kuderayov, V. N., and Lopes de Gerenyu, V. O.: Updated estimate of carbon balance on Russian territory, Tellus B, 62, 497-505, 2010a.

Kurganova, I. N., Lopes de Gerenyu, V. O., Shvidenko, A. Z., Sapozhnikov, P. M.: Changes in the organic carbon pool of abandoned soils in Russia (1990-2004), Eurasian Soil Sci., 43, 333 340, 2010b.

Larionova, A. A., Rozonova, L. N., Yevdokimov, I. V., Yermolayev, A. M., Kurganova, I. N., and Bagodatsky, S. A.: Land-use change and management effects on carbon sequestration in soils of Russia's South Taiga zone, Tellus B, 55, 331-337, 2003.

Lucht, W., Prentice, I. C., Myneni, R. B., Sitch, S., Friedlingstein, P., Cramer, W., Bousquet, P., Buermann, W., and Smith, B.: Climatic control of the high-latitude vegetation greening trend and Pinatubo effect, Science, 296, 1687-1689, 2002.

Luyssaert, S., Ciais, P., Piao, S. L., Schulze, E.-D., Jung, M., Zaehle, S., Schelhaar, M. J., Reichstein, M., Churkina, D., Papale, D., Abril, G., Beer, C., Grace, J., Lousteau, D., Matteicci, G., Magnagni, F., Nabuurs, G. J., Verbeek, H., Sulkava, M., van der Werf, G. R., Jansssens, I. A., and members of the CarboEurope Synthesis team: The European carbon balance, Part 3: Forests, Glob. Change Biol., 16, 1429-1450, 2010.

Lyuri, D. I., Goryachkin, S. V., Karavaeva, N. A., and Nefedova, T. G.: Dynamics of agricultural land of Russia in XX century and postagrogenic restoration of vegetation and soils, Moscow, 
GEOS, 416 pp., 2010 (in Russian).

Maksyutov, S., Machida, T., Mukai, H., Patra, K., Nakazawa, T., Inoue, G., Baker, D., Bousquet, P., Bruhwiler, L., Chen, Y.-H., Ciais, P., Denning, A. S., Fan, S., Fung, I. Y., Gloor, M., Gurney, K. R., Heimann, M., Higuchi, K., John, J., Law, R. M., Maki, T., Peylin, P. Prather, M., Pak, B., Rayner, P. J., Sarmiento, L., Taguchi, S., Takahashi, T., and Yuen, C. W.: Effect of recent observations on Asian $\mathrm{CO}_{2}$ flux estimates by transport model inversions, Tellus B, 55, 522-529, 2003.

Meybeck, M., Durr, H. H., and Vorosmarty, C. J.: Global coastal segmentation and its river catchment contributors: a new look at land-ocean linkage, Global Biogeochem. Cy., 20, GB1S90, doi:10.1029/2005GB002540, 2006.

McGuire, A., Anderson, L., Christensen, T., Dallimore, S., Guo, L., Hayes, D., Heimann, M., Lorenson, T., Macdonald, R., Roulet, N.: Sensitivity of the carbon cycle in the Arctic to climate change, Ecol. Monogr., 79, 523-555, 2009.

McGuire, A. D., Hayes, D. J., Kicklighter, D. W., Manizza, M., Zhuang, Q., Chen, M., Follows, M. J., Gurney, K. R., McClelland, J. W., Melillo, J. M., Peterson, B. J., and Prinn, R. G.: Analysis of the carbon balance of boreal Asia from 1997 to 2006, International Conference and Early Career Scientists School on Environmental Observations, Modeling and Information Systems ENVIROMIS-2010, 5-11 July 2010, Tomsk, Russia, 53$58,2010$.

McGuire, A. D., Christensen, T. R., Hayes, D., Heroult, A., Euskirchen, E., Kimball, J. S., Koven, C., Lafleur, P., Miller, P. A., Oechel, W., Peylin, P., Williams, M., and Yi, Y.: An assessment of the carbon balance of Arctic tundra: comparisons among observations, process models, and atmospheric inversions, Biogeosciences, 9, 3185-3204, doi:10.5194/bg-9-3185-2012, 2012.

Mollicone, D., Eva, H. D., and Achard, F.: Ecology: Human role in Russian wild fires, Nature, 440, 436-437, 2006.

Myneni, R. B., Keeling, C. D., Tucker, C. J., Asrar, G., and Nemani, R. R.: Increased plant growth in the northern high latitudes from 1981 to 1991 , Nature, 386, 698-702, 1997.

Nilsson, S., Shvidenko, A., Stolbovoi, V., Gluck, M., Jonas, M., and Obersteiner, M.: Full Carbon Account for Russia. Interim Report, IR000-021, available at: http://webarchive.iiasa.ac.at/ Publications/Documents/IR-00-021, Laxenburg, Austria, International Institute for Applied Systems Analysis, 180 pp., 2000.

Nilsson, S., Vaganov, E. A., Shvidenko, A. Z., Stolbovoi, V., Rozhkov, V. A., McCallum, I., and Jonas, M.: Carbon budget of vegetation ecosystems of Russia, Doklady Earth Sci., 393A, 1281-1283, translated from: Doklady Akad. Nauk, 393, 541543, 2003

Pan, Y., Birdsey, R. A., Fang, J., Houghton, R., Kauppi, P. E., Kurz, W. A., Phillips, O. L., Shvidenko, A., Lewis, S. L., Canadell, J. G., Ciais, P., Jackson, J. B., Pacala, S., McGuire, A. D., Piao, S., Rautiainen, A., Sitch, S., and Hayes, D.: A large and persistent carbon sink in the world's forests, Science, 333, 988-993, 2011.

Papale, D., Reichstein, M., Aubinet, M., Canfora, E., Bernhofer, C., Kutsch, W., Longdoz, B., Rambal, S., Valentini, R., Vesala, T., and Yakir, D.: Towards a standardized processing of Net Ecosystem Exchange measured with eddy covariance technique: algorithms and uncertainty estimation, Biogeosciences, 3, 571-583, doi:10.5194/bg-3-571-2006, 2006.

Parmentier, F. J. W., van der Molen, M. K., van Huissteden, J., Karsanaev, S. J., Kononov, A. A., Suzdalov, D. A., Maximov, T.
C., and Dolman, A. J.: Longer growing seasons do not increase net carbon uptake in the northeastern Siberian tundra, J. Geophys. Res., 116, G04013, doi:10.1029/2011JG001653, 2011.

Petrescu, A. M. R., van Beek, L. P., van Huissteden, J., Prigent, C., Sachs, T., Corradi, C. A. R., Parmentier, F. J. W., and Dolman, A. J.: Modeling regional to global $\mathrm{CH}_{4}$ emissions of boreal and arctic wetlands, Global Biogeochem. Cy., GB4009, doi:10.1029/2009GB003610, 2010.

Piao, S. L., Ciais, P., Friedlingstein, P., Peylin, P., Reichstein, M., Luyssaert, S., Margolis, H., Fang, J., Barr, A., Chen, A., Grelle, A., Hollinger, D. Y., Laurila, T., Lindroth, A., Richardson, A. D., and Vesala, T.: Net carbon dioxide losses of northern ecosystems in response to autumn warming, Nature, 451, 49-53, 2008.

Piao, S., Wang, X., Ciais, P., Zhu, B, Wang, T., and Liu, J.: Changes in satellite-derived vegetation growth trend in temperate and boreal Eurasia from 1982 to 2006, Glob. Change Biol., 17, 32283239, doi:10.1111/j.1365-2486.2011.02419.x, 2011.

Quegan, S., Beer, C., Shvidenko, A., McCallum, I., Handoh, I. C., Peylin, P., Rödenbeck, C., Lucht, W., Nilsson, S., and Schmullius, C.: Estimating the carbon balance of central Siberia using a landscape-ecosystem approach, atmospheric inversion and Dynamic Global Vegetation Models, Glob. Change Biol., 17, 351365, 2011.

Reichstein, M., Falge, E., Baldocchi, D., Papale, D., Aubinet, M., Berbigier, P., Bernhofer, C., Buchmann, N., Gilmanov, T., Granier, A., Grunwald, T., Havrnkov, K., Ilvesniemi, H., Janous, D., Knohl, A., Laurila, T., Lohila, A., Loustau, D., Matteucci, G., Meyers, T., Miglietta, F., Ourcival, J., Pumpanen, J., Rambal, S., Rotenberg, E., Sanz, M., Tenhunen, T., Seufert, G., Vaccari, F., Vesala, T., Yakir, D., Valentini, R.: On the separation of net ecosystem exchange into assimilation and ecosystem respiration: review and improved algorithm, Glob. Change Biol., 11, 14241439, 2005.

Roedenbeck, C., Houweling, S., Gloor M., Heimann , M.: Time-dependent atmospheric $\mathrm{CO}_{2}$ inversions based on interannually varying tracer transport Tellus B, 55, 488-497, doi:10.1034/j.1600-0889.2003.00033.x, 2003.

Rodin, A. Z. and Krylatov, A. K. (Eds.): Dynamic of Humus Balance on Cropland of the Russian Federation, Moscow, Goskomzem, 60 pp., 1998.

Romankevich, E. A. and Vetrov, A. A.: Carbon cycle in Arctic seas of Russia, Nauka, Moscow, Russia, 302 pp., 2001 (in Russian).

Roshydromet: Report about peculiarities of climate in territories of Russian Federation, Federal Agency on Hydrometeorology of the Russian Federation, Moscow, 2011 (in Russian).

Rozanov, A. V.: Methane emissions from forest and agricultural land in Russia, WP-95-31, Laxenburg, Austria, International Institute for Applied Systems Analysis, 37 pp., 1995.

Schepaschenko, D., McCallum, I., Shvidenko, A., Steffen, F., Kraxner, F., and Obersteiner, M.: A new hybrid land cover dataset for Russia: a methodology for integrating statistics, remote sensing and in-situ information, J. Land Use Sci., 6, 245-259, 2011a.

Schepaschenko, D. G., Shvidenko, A. Z., Mukhortova, L. V., and Schepaschenko, M. V.: Soil in estimation of biospheric role of terrestrial ecosystems of Russia, Proceedings of Int. Science Conference "Resource Potential of Soils - a Background of Food and Ecological Safety of Russia", St. Petersburg, 1-4 March 2011, St. Petersburg State University, ISBN 978-5-288-05155-5, 511-512, 2011b (in Russian). 
Schepaschenko, D., Shvidenko, A., and Schepaschenko, M.: Carbon balance of Russian agricultural land, EGU General Assembly 2012, Geophys. Res. Abstr., 14, EGU2012-8544, 2012a.

Schepaschenko, D. G., Mukhortova, L. V., Shvidenko, A. Z., and Vedrova, E. F.: Organic carbon stock in soil of Russia, Eurasian Soil Sci., accepted, 2012b.

Schulze, E.-D., Ciais, P., Luysaert, S., Freibauer, A., Janssens, I. A., Sousanna, J. F., Smith, P., Grace, J., Levin, I., Thiruchittampalam, B., Heimann, M., Dolman, A. J., Valentini, R., Bousquet, P., Peylin, P., Peters, W., Roedenbeck, C., Etiope, G., Vuichard, N., Wattenbach, M., Nabuurs, G. J., Poussi, Z., Nieschulze, J., Gash, J. H. C., and the CarboEurope Team: Importance of methane and nitrous oxide for Europe's terrestrial greenhouse gas balance, Nat. Geosci., 2, 842-850, 2009.

Schuur, E., Bockheim, J., Canadell, J., Euskirchen, E., Field, C., Goryachkin, S., Hagemann, S., Kuhry, P., Lafleur, P., and Lee, H.: Vulnerability of permafrost carbon to climate change: implications for the global carbon cycle, BioScience, 58, 701-714, 2008.

Seiler, W. and Crutzen, P. J.: Estimates of gross and net fluxes of carbon between the biosphere and the atmosphere from biomass burning, Climatic Change, 2, 207-247, 1980.

Serreze, M. C. and Barry, R. G.: Processes and impacts of Arctic amplification: A research synthesis, Global Planet. Change, 77, 85-96, doi:10.1016/j.gloplacha.2011.03.004, 2011.

Serreze, M. C., Walsh, J. E., Chapin, F. S., Osterkamp, T., Dyurgerov, M., Romanovsky, V., Oechel, W. C., Morison, J., Zhang, T., Barry, R. G.: Observational Evidence of Recent Change in the Northern High-Latitude Environment, Climatic Change, 46, 159-207, doi:10.1023/A:1005504031923, 2000.

Shvidenko, A., and Nilsson, S.: A synthesis of the impact of Russian forests on the global carbon budget for 1961-1998, Tellus B, 55, 391-415, 2003.

Shvidenko, A., Schepschenko, D., Nilsson, S., and Bouloui, Y.: Semi-empirical models for assessing biological productivity of Northern Eurasian forests, Ecol. Model., 204, 163-179, 2007.

Shvidenko, A., Schepaschenko, D., and McCallum, I.: Bottom-up inventory of the carbon fluxes in Northern Eurasia for comparison with GOSAT Level 4 Products, Report, International Institute for Applied Systems Analysis, Laxenburg, Austria, 225 pp., 2010a.

Shvidenko, A., Schepaschenko, D., McCallum, I., and Nilsson, S.: Can the uncertainty of full carbon accounting of forest ecosystems be made acceptable to policymakers?, Climatic Change, 103, 137-157, 2010b.

Shvidenko, A., Schepaschenko, D., and Maksyutov, S.: Impact of terrestrial ecosystems of Russia on the global carbon cycle from 2003-2008: An attempt of synthesis, Proceedings of the International Conference on Environmental Observations, Modeling and Information ENVIROMIS-2010, 5-11 July 2010, Tomsk, Russia Tomsk, 48-52, 2010c.

Shvidenko, A., Schepaschenko, D., Vaganov, E., Sukhinin, A., McCallum, I., Maksyutov, S., and Lakyda, I.: Impacts of vegetation fire in Russian territories on ecosystems and global carbon budget in 1998-2010, Doklady Earth Sci., 441, 1678-1682, 2011.
Sitch, S., Huntingford, C., Gedney, N., Levy, P. E., Loman, M., Piao, S.-L., Betts, R., Ciais, P., Cox, P., Friedlingstein, P., Jones, C. D., Prentice, I. C., and Woodward, F. I.: Evaluation of the terrestrial carbon cycle, future plant geography and climate-carbon cycle feedbacks using five Dynamic Global Vegetation Models (DGVMs), Glob. Change Biol., 14, 2015-2039, 2008.

Soja, A. J., Sukhinin, A. I., Cahoon Jr., D. R., Shugart, H. H., and Stackhouse Jr., P. W.: ABHRR-derived fire frequency, distribution and area burned in Siberia, Int. J. Remote Sens., 25, 19391960, 2004.

Solontsov, O. N.: Development of state forest inventory in Russian Federation, II International conference "Problems of forest management and state forest inventory in Russia" 8-10 December 2010, Vologda, Russia, available at: http://www. roslesinforg.ru/press/news/35/O.N._Solontcov_Napravleniya razvitiya_gosudarstvennoj_inventarizatcii_lesov_v_Rossii.pdf, 2010.

Tarnocai, C., Canadell, J. G., Schuur, E. A. G., Kuhry, P., Mazhitova, G., and Zimov, S.: Soil organic carbon pools in the northern circumpolar permafrost region, Global Biogeochem. Cy., 23, GB2023, doi:10.1029/2008GB003327, 2009.

van der Werf, G. R., Randerson, J. T., Giglio, L., Collatz, G. J., Mu, M., Kasibhatla, P. S., Morton, D. C., DeFries, R. S., Jin, Y., and van Leeuwen, T. T.: Global fire emissions and the contribution of deforestation, savanna, forest, agricultural, and peat fires (19972009), Atmos. Chem. Phys., 10, 11707-11735, doi:10.5194/acp10-11707-2010, 2010.

Vuichard, N., Ciais, P., Belelli Marchesini, L., Smith, P., and Valentini, R.: Carbon sequestration due to the abandonment of agriculture in the former USSR since 1990, Global Biochem. Cy., 22, GB4018, doi:10.1029/2008GB003212, 2008.

Wang, T., Ciais, P., Piao, S. L., Ottlé, C., Brender, P., Maignan, F., Arain, A., Cescatti, A., Gianelle, D., Gough, C., Gu, L., Lafleur, P., Laurila, T., Marcolla, B., Margolis, H., Montagnani, L., Moors, E., Saigusa, N., Vesala, T., Wohlfahrt, G., Koven, C., Black, A., Dellwik, E., Don, A., Hollinger, D., Knohl, A., Monson, R., Munger, J., Suyker, A., Varlagin, A., and Verma, S.: Controls on winter ecosystem respiration in temperate and boreal ecosystems, Biogeosciences, 8, 2009-2025, doi:10.5194/bg8-2009-2011, 2011.

Zamolodchikov, D. G. and Utkin, A. I. A.: System of Conversion Relations for Calculating the Net Primary Production of Forest Ecosystems from Tree Stocks, Lesovedenie, 6, 54-63, 2000.

Zavarzin, G. A. (Ed.): Carbon pools and fluxes in terrestrial ecosystems of Russia, Moscow, Nauka, 316 pp., 2007.

Zelenev, V. V.: Assessment of the Average Annual Methane Flux from the Soils of Russia, WP-96-51, International Institute for Applied Systems Analysis, Laxenburg, Austria, 45 pp., 1996.

Zhou, L., Tucker, C. J., Kaufmann, R., Slayback, D., Shabanov, N. V., and Myneni, R. B.: Variations in northern vegetation activity inferred from satellite data of vegetation index during 1981 to 1999, J. Geophys. Res., 106, 20069-20083, doi:10.1029/2000JD000115, 2001.

Zimov, S., Davydov S., and Zimova, G.: Permafrost carbon: Stock and decomposability of a globally significant carbon pool, Geophys. Res. Lett., 33, L20502, doi:10.1029/2006GL027484, 2006. 